\title{
Recovery and exit of zombie firms in Portugal
}

\author{
Carlos Carreira $(1)$ Paulino Teixeira (iD) \\ Ernesto Nieto-Carrillo (i)
}

\begin{abstract}
The resources sunk in zombie firms have risen over the last two decades, hampering productivity growth in developed economies. In this paper, we examine the recovery and exit of zombie firms among small- and medium-sized enterprises (SME), as well as the determinants of these transitions. To our knowledge, this is the first study on the determinants of the probability of a zombie recovering or exiting in a European context. The study also contributes to the discussion of the definition of zombie firms. Based on a panel of Portuguese manufacturing and services firms covering the 2004-2017 period, we do find a widespread presence of zombies. As expected, they are relatively less productive than non-zombies, while the probability of transition into recovery and exit is relatively low, which we interpret as evidence in favour of the presence of high barriers to firm mobility. In turn, the regression results show that downsizing and restructuring, as well as debt restructuring, are crucial in enhancing recovery of zombie firms. These are non-trivial results from the perspective of managers and policy makers. We performed several exercises using alternative definitions of zombie firms and estimation techniques and found that our findings are robust.
\end{abstract}

C. Carreira $(\bowtie) \cdot$ P. Teixeira $\cdot$ E. Nieto-Carrillo Faculty of Economics, and CeBER, University of Coimbra, Coimbra, Portugal

e-mail: ccarreir@fe.uc.pt
Plain English Summary A 1\% decline in the share of highly indebted and unprofitable firms (i.e. zombies) is estimated to increase the average labour productivity by 3.1 percent. Recovery of zombies in particular can be enhanced by downsizing and restructuring. Based on a very large panel of Portuguese small- and medium-sized manufacturing and services firms, covering the 20042017 period, we do find a widespread presence of zombie firms. Moreover, the chance of these firms to recover or exit is relatively low, an evidence of the presence of high barriers to firm mobility and resource misallocation. Our results have important managerial and policy implications: (1) a coordinated and holistic restructuring strategy (technological, operational and debt-related) is crucial to increase the likelihood of recovery of weak companies; (2) governments should formulate an adequate institutional framework in order to strengthen the selection of zombie firms, namely by designing more reallocationfriendly insolvency regimes and discouraging creditors to refinance unviable firms.

Keywords Zombie firms · exit · recovery · restructuring · downsizing

JEL Classifications D24 - G32 - G33 · L25 - L26 - O47

\section{Introduction}

Zombie firms, that is, mature firms that are debt-ridden and have no potential to repay their debt due to lack of profitability over an extended period, have attracted 
increasing attention from researchers and policy-makers in recent years. The reason is a simple one: zombie firms, which should have been compelled by competitive forces to restructure or exit the market, have increasingly become survivors in advanced economies. By hindering competition, this process has hampered economic growth by mainly constraining the growth of more productive firms. A reduction in the share of zombies is therefore expected to generate important economic gains (Caballero et al., 2008; McGowan et al., 2017a).

In this paper, we contribute to this strand of literature by analysing why most zombie firms recover rather than exit the market, and the determinants of these transitions. We address in particular the following issues: how can zombie firms survive for long periods? Are they inherently unviable? And what are the factors that drive zombies to recover rather than exiting?

To study the transitions out of the zombie state, we use a multinomial logistic model where "non-transition", "recovery" and "exit" are treated as distinct and unordered categories. Results from an ordered logistic model are also discussed in a separate robustness section. The analysis is based on the population of Portuguese firms in the manufacturing and services industries over the period of 2004-2017. During this interval, the Portuguese economy was seriously hit by the Great Recession, with an average annual growth rate of real gross domestic product (GDP) of $-1.3 \%$ between 2008 and 2013 and a trough of $-4.1 \%$ in 2012 . We use the methodology proposed by Schivardi et al. (2017) to identify zombie firms. As a distinct feature of our approach, however, we assume that forbearance lending does not come only from banks, as presumed in previous literature, but also from all the creditors.

Inspired by the seminal work of Caballero et al. (2008), there is a growing body of studies analysing the role of zombie firms, although mostly focused on market congestion and aggregate growth issues (e.g. Caballero et al., 2008; McGowan et al., 2017a). Transitions within zombie firms in particular have not been addressed in detail, with the exception of the studies by Fukuda and Nakamura (2011) and Nakamura (2017) which explicitly examine how zombie firms have recovered based on a very limited sample of listed large Japanese firms. To the best of our knowledge, our paper is the first to study the determinants of the likelihood of zombie firms among small- and medium-sized enterprises (SME) to recover (or exit) in a European country. It also has the advantage of providing industry- and servicewide evidence. As a distinct feature too, the paper offers a methodological contribution to the definition of zombie firms. Namely, we argue that forbearance can occur when, outside of the normal terms of business, a bank or any other creditor seeks to provide support to a firm struggling to meet its obligations. In this context, "profitability" and "default risk" are more informative than the "subsidised" interest rate criterion as a means of identification of zombie firms.

We found that most zombie firms are "entrenched", that is, with a higher probability of non-transition into alternative states, which we interpret as evidence in favour of the presence of high barriers both to recovery and exit. There is, however, a good chance that zombie firms do recover, being this process more likely whenever there is downsizing and restructuring, as well as debt restructuring, especially if accompanied by an overall economic upturn. These are of course important results from the point of view of managers and policy makers.

The remainder of the paper is organised as follows. Section 2 reviews previous research on zombies, while Section 3 defines zombie firms and describes some key aspects of the dataset. Section 4 describes the dynamics of zombie firms during the 2008-2013 Great Recession and in its aftermath. It also reports the estimation results from a multinomial logistic model. Robustness checks are presented in Section 5, while Section 6 contains some concluding remarks, including possible policy implications and research directions for the future.

\section{Related literature and basic model}

The genesis of the debate on zombie firms can be traced back at least to the study of the Japanese stagnation at the end of the 20th century by Peek and Rosengren (2005) and Caballero et al. (2008). Both studies emphasised that during this period, there was a misallocation of financial resources that fostered a delay in the exit of unproductive firms. Faced with a negative economic shock, the economic recovery is not only affected by the preservation of these less viable firms (zombie firms), which would not survive without "subsidised" loans, but also because these firms congest the market and, as a 
consequence, hamper the growth of more profitable projects (the "sclerosis" and "scrambling" effects, respectively; Caballero \& Hammour, 1998, 2000). It should be noted that the latter effect is not less important than the former. In fact, most of the aggregate productivity growth is better explained by the withinfirm effect than by the reallocation process (Bartelsman \& Doms, 2000; Foster et al., 2008; Syverson 2011). As a matter of fact, Caballero et al. (2008) found that the increase in the share of zombie firms in an industry is associated with a reduction in aggregate productivity and an increase in the productivity gap between zombies and non-zombies. Throughout this process, investment and employment growth of non-zombie firms are depressed. Kwon et al. (2015) actually estimate that without lending by banks to zombies, the annual aggregate productivity growth of the Japanese economy would increase by one percentage point during the 1990s.

The study by Caballero et al. (2008) has been replicated in other countries with broadly similar results - e.g. Tan et al. (2016), for the Chinese economy in the 2005-2007 period; McGowan et al. (2017a), for nine OECD countries over the period 2003-2013; ${ }^{1}$ Andrews and Petroulakis (2017), for 11 European countries over the period 2001-2014; ${ }^{2}$ and Gouveia and Osterhold (2018), for Portugal in the 2006-2015 period.

Restructuring and exit barriers play an important role in the dynamics of zombie incidence. These barriers are not only associated with evergreen loans - i.e. the situation in which banks make additional credits to problematic borrowers to avoid reporting losses on their own balance sheets (Peek \& Rosengren, 2005). McGowan et al. (2017b) highlighted that greater barriers to restructuring would be associated with a lower probability of recovery of the zombie firms, as well as with a higher probability of healthy firms becoming zombies. They would also have a negative effect on the efficiency in which capital is reallocated, given the reduction in the capacity of the most productive firms to attract capital, especially in sectors with a higher growth

\footnotetext{
${ }^{1}$ The analysis comprises the following countries: Belgium, Finland, France, Italy, Korea, Slovenia, Spain, Sweden and the United Kingdom. In addition, for the 2013 cross-sectional study, Austria, Germany, Luxembourg and Portugal were added.

${ }^{2}$ Austria, Denmark, Estonia, France, Germany, Greece, Latvia, Slovenia, Spain, Portugal, United Kingdom.
}

potential. In particular, the authors estimate that a reduction in the restructuring barriers in Italy and Greece, as well as a decrease in personal costs associated with entrepreneurial failure in the case of Spain, would result in a decrease in the zombie capital share of at least 9 percentage points in all three countries.

In the same vein, McGowan et al. (2017c) emphasised that the reduction in personal costs related with business failure would facilitate the decongestion of the market, providing greater opportunities for new firms and for the growth of the non-zombies. Furthermore, they found that reforms in insolvency regimes that reduce barriers to restructuring are associated with higher growth in the productivity of laggard firms, especially in industries with structurally more entry and exit and higher dependence on external financing.

The emphasis of this paper is not so much on the effects of zombies on productivity growth. We focus rather on the determinants of the recovery and exit of zombie firms, which have rarely been examined in this context. Figure 1 illustrates our basic model. We assume that, in each period, a mass of zombie firms implement downsizing and restructuring strategies. Successful ones recover, while unsuccessful zombies die. Another mass of zombies does not implement any strategy, which means that at best they remain as zombies.

One comparable exercise was conducted by Fukuda and Nakamura (2011), who studied the nature of corporate restructuring strategies adopted by the zombie firms that were effective in promoting their recovery. Using data on listed Japanese firms between 1995 and 2004, they found that the strategy of reducing the size, both in terms of employees and assets, was effective in reviving firms in trouble. They also emphasised that the sale of their prime assets was detrimental to the recovery as it delayed the restructuring process. Accordingly, only the recovery through the sale of assets seems to be effective as long as they correspond to the category of unutilised fixed assets.

In a follow-up study, Nakamura (2017) showed that the downsizing strategy had positive effects on the probability of recovery only after the reform of the banking sector in the early 2000s, which included better accounting rules and supervision policies. The author also stressed that "restructuring without innovation was not useful for over-coming prolonged deflation, even in a favourable external macroeconomic environment." 
Fig. 1 Basic model

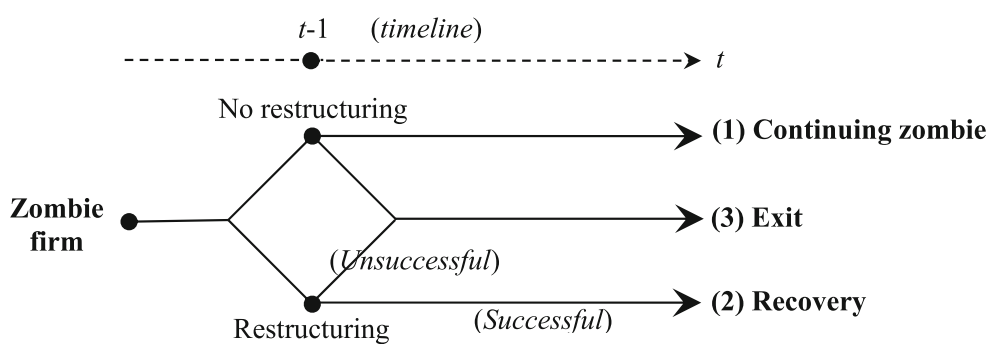

\section{Data and identification of zombie firms}

\subsection{The dataset}

The raw data used in this study is drawn from Integrated Business Accounts System (Sistema de Contas Integradas das Empresas, SCIE). The SCIE is obtained from a process of statistical data integration based on annual administrative data from various business statistical sources, namely the Simplified Business Information (Informação Empresarial Simplificada, IES), administered by the Portuguese Statistical Office (Instituto Nacional de Estatistica, INE). The IES electronic delivery allows the whole population of Portuguese enterprises pertaining to the non-financial business sector (regardless of whether or not they are active) to fulfil their all legal obligations on a single procedure, including the delivery of annual accounting and tax statements to the Tax Authority and provision of statistical information to the Portuguese Statistical Office.

The sample used in our study covers manufacturing and services industries, except utilities, the financial sector, and education, health and cultural services, for the period 2004-2017. ${ }^{3}$ We exclude from our sample micro-enterprises that persistently have less than three employees, generally self-employment enterprises, for which generating profits, growing and innovating is not the primary motivation. ${ }^{4}$

Each firm in the SCIE has a fixed identification number, so that every single unit can be easily followed longitudinally. As in Carreira and Teixeira (2016), firm exit is flagged when a unit ceases production activity permanently. In general, this occurs simultaneously with the legal death of the firm (i.e. when the firm identifier disappears from the dataset). However, if a

\footnotetext{
${ }_{3}^{3}$ Typically, education, health and cultural services enterprises show clear differences in firm characteristics, especially with respect to funding of production activities.

${ }^{4}$ The main objective in this case is rather to generate enough activity and revenue for themselves (namely, for the family).
}

given unit ceases production in $t$ and the legal death is in $t+\tau$, while no production is observed between $t$ and $t+$ $\tau$, then $t$ is coded as the year of death. ${ }^{5}$

Some preliminary filtering of the raw data was required. First, since we are ultimately concerned with market congestion caused by zombies, all effectively inactive firms were discarded. ${ }^{6}$ Second, observations with unreasonable values (e.g. non-positive output, total net assets or total debt) were discarded. Finally, given the requirement of at least three consecutive years of firm-level observations for identification of zombie firms (see definition in Section 3.2), 1-year reporting gaps are interpolated linearly. Our final sample comprises an unbalanced panel of 273,907 firms making up 2,165,915 year-firm observations. Table 9 in Appendix presents the list of the selected industries and the corresponding summary statistics.

\subsection{Defining zombie firms}

Our first task was to identify those firms that could be flagged as zombies, and to that end, several strategies have been proposed in the literature. Caballero et al. (2008), for example, define zombie firms as those receiving subsidised credit, that is, those whose actual interest rate paid is lower than the hypothetical riskfree interest rate (weighted by the firm debt structure). However, although zombie firms are conceptually associated with evergreen lending, this very aspect is ignored in the definition of Caballero et al. (2008). An identification of zombie firms that is only based on the

\footnotetext{
${ }^{5}$ One of weaknesses of the SCIE is the lack of information concerning mergers and acquisitions. In effect, we cannot distinguish a true exit from an exit generated by a merger or acquisition. However, this limitation is not likely to have an impact upon our results. According to Mata and Portugal (2004), mergers and acquisitions are rare and negligible events that do not exceed $1 \%$ of the exits. Moreover, these events are likely to be even more negligible in a context of zombie firms.

${ }^{6}$ Inactive firms are generally in liquidation, dissolved or in receivership.
} 
subsidised credit criterion is particularly prone to two types of errors. First, healthy firms could be misclassified as zombies if they pay their interest at the rates below prime lending rates given their low credit risk. Second, zombie firms can also be misclassified as non-zombies if they pay their interest at the rates prevailing in the market as a result of evergreen loans (i.e. loans where the bank is rolling over the loan at the normal interest rate). ${ }^{7}$ In order to overcome these shortcomings, Fukuda and Nakamura (2011) considered two further aspects: "profitability" and "evergreen lending". According to the former, firms whose operating income exceeds the hypothetical risk-free interest payment should not be classified as zombies, while, according to the latter, unprofitable highly leveraged firms with increasing external borrowings should be classified as zombies.

In any event, the method proposed by Caballero et al. (2008) cannot be replicated using our SCIE dataset. The main reason is that this method requires detailed information on the debt structure of each firm which is not available. We recall that the data in Caballero et al. (2008) and Fukuda and Nakamura (2011) is restricted to listed firms which makes such information more easily available. We cannot observe actual interest payments on different forms of debt either. An alternative is to use interest coverage ratios. For example, McGowan et al. (2017a) classify a firm as zombie whenever: (i) it has an interest coverage ratio (i.e. the ratio of operating income to interest expenses) of less than one over three consecutive years and (ii) it is older than 10 years. The 3 -year restriction is important to ensure that the zombie status is not driven by business cycle fluctuations, while firm age above 10 allows the distinction between zombie firms and young innovative start-ups. This procedure has, however, two major drawbacks in the context of our analysis. First, zombie firms are usually associated with "subsidised" interest payments. Moreover, when interest rates are very low for a long period, subsidised lending rates tend to be near zero (or even negative). As a result, it may be difficult in practice to identify zombie firms through interest coverage ratios (Banerjee \& Hofmann, 2018). A second reason is that a change in accounting standards has taken place in 2010 ,

\footnotetext{
${ }^{7}$ During the Japanese banking crisis of the 1990s, Peek and Rosengren (2005) observed that troubled banks allocate credit to severely impaired borrowers to avoid realization of losses on their own balance sheets.
}

making the (total) interest expenses only observable in the SCIE dataset in the 2010-2017 interval.

The characteristics of the firm can also be used to identify firms with persistent financial problems. Typically, these measures combine indicators of low profitability and high default risk. For example, Schivardi et al. (2017) propose the use of the following "profitability" and "default risk" criteria: (i) return-on-assets - measured as the threeyear moving average of Earnings Before Interest, Taxes, Depreciation and Amortisation (EBITDA) over total assets-below the low-risk interest rate; and (ii) leverage (total financial debt over total assets) above the median in the low return-onassets exiting group. Shen and Chen (2017) also define zombie firms as those who (i) are capable of obtaining more debt, although they (ii) are already debt-ridden (leverage above 50\%) and (iii) have no potential to repay that debt (negative operating profits for three consecutive years). In turn, Storz et al. (2017) classify a firm as zombie whenever for two consecutive years: (i) its return-on-assets (measured as net income over total assets) is negative, (ii) its net investment is negative and (iii) its debt servicing capacity (measured as EBITDA over total financial debt) is lower than the median value.

Following Schivardi et al. (2017), in this study, a firm is classified as a zombie whenever: (i) its return-onassets is lower than the low-risk interest rate at least for a period of three consecutive years, (ii) its leverage is higher than the industry-median (at the two-digit NACE Rev.2 level) of the low return-on-assets exiting group and (iii) it is older than 5 years. ${ }^{8}$ The rationale is that firms that are already debt-ridden and have no potential to repay their debt are likely to be on the verge of exit, unless their creditors sustain their continuation. The return-on-assets is defined as EBITDA over total assets. We compare return-on-assets with the annual average Euribor 12-month interest rate, the reference interest rate commonly used for loans by the Portuguese banking sector. The rationale is that EBITDA is what is left of

\footnotetext{
${ }^{8}$ The investment projects of young firms need time to deliver returns. The 5-year age threshold is chosen because it is the age limit defined by the OECD for young high-growth firms (Ahmad, 2006; Koski \& Pajarinen, 2013). Most studies point out that firms achieve the mature state somewhere between the sixth and tenth year of existence (Carreira $\&$ Teixeira, 2011). We also checked the 10 -year limit used by McGowan et al. (2017a), as a robustness test, with no major changes in the results. These results are available from the authors on request.
} 
revenues to remunerate the capital after paying labour and intermediates inputs. The leverage is defined as the ratio of the sum of debt in current liabilities and longterm debt to total assets. That is, we assume that the financial protection of zombie firms does not come only from banks forbearance, as in previous literature, but also from all types of creditors, a key issue in the context of Portuguese economy. In fact, on average, between 2010 and 2017, a quarter of total debts observed in our dataset was to suppliers. Moreover, according to the information provided by the "European Payment Industry" (INTRUM, 2018), late payment is a big issue in the Portuguese economy, being especially relevant in the "business to business" relationships, whose "average contractual payment terms" and "average time that actually take to pay" rates are about 60 and 70 days, respectively (the highest rates in Europe).

As in Nakamura (2017), we screen the zombie identification by excluding "one-shot zombie" firms from the zombie group (i.e. one-off zombies or false zombies). Conversely, we include "one-shot restructuring" firms, that is, zombie firms that become non-zombies in $t+1$ and zombies again in $t+2$ (i.e. false restructurings).

Other definitions of zombie firms could have also been used. In Section 5, we provide a robustness analysis of the findings to alternative definitions of zombie firms using Shen and Chen (2017), Schivardi et al. (2017) and McGowan et al. (2017a). Our expectation is that the results will not be sensitive to the selected criteria given our focus on the dynamics of zombies. McGowan et al. (2017a) also tested different variations of their own criteria, with no visible sensitivity, while Schivardi et al. (2017) and Storz et al. (2017) replication of McGowan et al. definition produced only a very limited impact on the results.

Table 10 shows indeed that our definition of zombie firms is highly positively and significantly correlated with those of Shen and Chen (2017) and Schivardi et al. (2017), while the correlation with the definition of McGowan et al. (2017a) is moderately positive. McGowan et al. (2017a) have shown in turn that their zombie definition is positively and significantly correlated with that of Caballero et al. (2008).

\subsection{Productivity measure and other independent variables}

Firm-level total factor productivity (TFP) is our selected productivity measure. To compute the TFP, we estimate the factor elasticity parameters of the following CobbDouglas production function (in $\log$ form) for each industry (at two-digit NACE Rev.2 level):

$y_{\mathrm{it}}=\alpha_{0}+\alpha_{\mathrm{K}} k_{\mathrm{it}}+\alpha_{\mathrm{L}} l_{\mathrm{it}}+\alpha_{\mathrm{M}} m_{\mathrm{it}}$,

where $y_{\mathrm{it}}$ is the real gross output of the $i$ th firm in year $t$, and $k_{\mathrm{it}}, l_{\mathrm{it}}$ and $m_{\mathrm{it}}$ are the capital, labour and material (intermediate) inputs, respectively, and $\alpha_{\mathrm{f}}$ denotes the factor elasticities, $f=K, L, M$. The (log) TFP is thus defined as the log difference between firms' output and the weighted sum of inputs.

We also check the robustness of our results by using labour productivity (LP). Labour productivity is defined as gross value added (GVA) per worker, which is calculated as the difference between gross output and material inputs. The gross output is measured as the value of sales of goods and services, less the value of purchases of goods for resale, adjusted for changes in inventory of final goods, self-consumption of own production and other operating revenues. Gross output and GVA are deflated by the producer price index at the two-digit industry level, obtained from INE. The labour input is a 12-month employment average. Materials include the cost of materials and services purchased and were deflated by the GDP deflator index. Capital input is obtained by applying the perpetual inventory method to the change in total real assets (i.e. it includes not only tangible and intangible assets but also current assets, all important to the operation of the firm). In particular, for the first year in the time series of a firm, we have deflated the book value of total net assets by the GDP deflator index of that year, in order to derive the capital stock $K_{\mathrm{t}}$. For subsequent years, if the assets rise, then the increment is deflated by GDP deflator index of the current year and added to the $K_{\mathrm{t}-1}$ to yield $K_{\mathrm{t}}$. If it declines, $K_{\mathrm{t}}$ is reduced proportionately. Output and input variables are measured in constant 2011 Euro.

To overcome the well-known simultaneity and selection bias problem in estimating production function at firm level, we use the semi-parametric method proposed by Levinsohn and Petrin (2003) controlling for endogenous exit (Rovigatti \& Mollis, 2018). There are alternative ways to estimate factor elasticities; however, they tend to generate similar TFP results, even if they produce somewhat different elasticities (see, for example, van Biesebroeck, 2008; Syverson 2011). 


\section{Empirical analysis}

4.1 Incidence and characteristics of zombie firms

We start our empirical investigation by describing the pattern of zombie firms. Figure 2 shows the (unweighted) share of zombies in terms of the number of firms and according to three different (weighted) measures: debt, assets and employment. As expected, zombie firms are quite present in the Portuguese economy. On average, about $11 \%$ of the firms in the sample were classified as zombies in 2005-2016, while the share of employment and assets sunk in zombie firms is $6 \%$ and $7 \%$, respectively. One explanation for the difference between the unweighted and employment-weighted shares is of course that zombies tend to be smaller than nonzombies. As can be seen in Fig. 3, the share of zombie firms is about 6.3 percentage points larger among micro-enterprises (firms with less than 10 employees) than in SME. Unsurprisingly, in Fig. 2, the share of zombie firms in total corporate debt, which captures the implied bad debt ratio, is larger than the share in terms of number of firms, at $12 \%$, on average.

As shown in Figure 10 in Appendix, the results are robust to alternative definitions of zombie firms. Actually, our shares of zombie firms are on average 1.7 percentage points higher than those computed with the definition of interest coverage ratio of McGowan et al. (2017a) for the period 2010-2016, and 1.3 percentage points lower than those estimated with the original definition of Schivardi et al. (2017). And, clearly, the three alternatives show a similar pattern over time.

These shares broadly confirm the pattern observed in other European countries too, as reported by McGowan et al. (2017a) and Storz et al. (2017), for example. In particular, the shares of zombies (as a percentage of the total number of firms) in Fig. 2 are similar to those reported by Storz et al. (2017) for Portugal, whose percentage values range from less than $8 \%$ in 2010 to $12 \%$ in 2013, and they are higher than those found by Gouveia and Osterhold (2018) using interest coverage ratio definition, whose estimates range from $6.5 \%$ in 2008 to $8.5 \%$ in 2013.

Cyclical fluctuations clearly emerge from Fig. 2. The share of zombie firms declines from $10.4 \%$ in 2006 to $9.1 \%$ in 2009 ; then, it rises quickly to a peak in 2012 , at $12.7 \%$. This peak, which was also observed in Storz et al. (2017) and Gouveia and Osterhold (2018), corresponds to the austerity period, as a result of the implementation of the 2011 Memorandum of Understanding. By 2016, the percentage of zombies declined to $8.4 \%$.

To investigate the incidence of zombie firms at the disaggregate level, Fig. 4 depicts the corresponding shares by industry. While there are some differences across industries, the general pattern holds. The exception is the Accommodation and food services sector, where the percentage of zombie firms rose sharply from $7.0 \%$ in 2005 to $21.6 \%$ in 2014 , a sizeable increase of 14.6 percentage points. It appears that during bad times, non-performing firms in this industry are relatively more exposed to personal costs associated with failed entrepreneurship and barriers to restructuring, which unreasonably foster the survival of firms that would otherwise exit the market. ${ }^{9}$ On average, the other sectors exhibit values in a range of $5.2 \%$ (in business services) to $13.8 \%$ (in real estate). This pattern is also robust to manufacturing industry disaggregation, with seemingly differences: the average share of zombie firms ranges from $4.0 \%$ (in leather) to $10.1 \%$ (in wood and furniture) (Table 11 in Appendix).

Firm productivity is much weaker among zombies. Figure 5 displays the Kernel density estimate of the distribution of total factor productivity and labour productivity for zombie and non-zombie groups. On average, zombie firms are less productive than non-zombies, with the corresponding TFP and labour productivity distributions clearly located to the left of non-zombies. As shown in Table 1, zombie firms perform poorly not only with respect to productivity, but also regarding real GVA and EBITDA. They also have higher debt than non-zombie firms. Furthermore, the Wilcoxon-MannWhitney test indicates that the mean and median of all main firm characteristics of the two groups are statistically different at the $1 \%$ significance level. ${ }^{10}$ This gap between zombie and non-zombie firms seems to have been even higher in the crisis period (Table 13 in Appendix).

\footnotetext{
${ }^{9}$ The increase of the VAT rate for restaurants from $13 \%$ to $23 \%$ in 2012 is certainly an explanation for this large increase in the number of zombie firms.

${ }^{10}$ Given that both Shapiro-Wilk and Shapiro-Francia normality tests showed that the variables are not normally distributed, we used the Wilcoxon-Mann-Whitney test to compare zombie and no-zombie groups. These tests are available from the authors upon request.
} 
Fig. 2 Share of zombie firms, 2005-2016. Notes: Zombie firms are defined as firms older than 5 years with a return-on-assets below the low-risk interest rate over three consecutive years and a leverage ratio above the industry median of the low return-onassets exiting group. Assets, debt and employment refer to the share pertaining to zombie firms

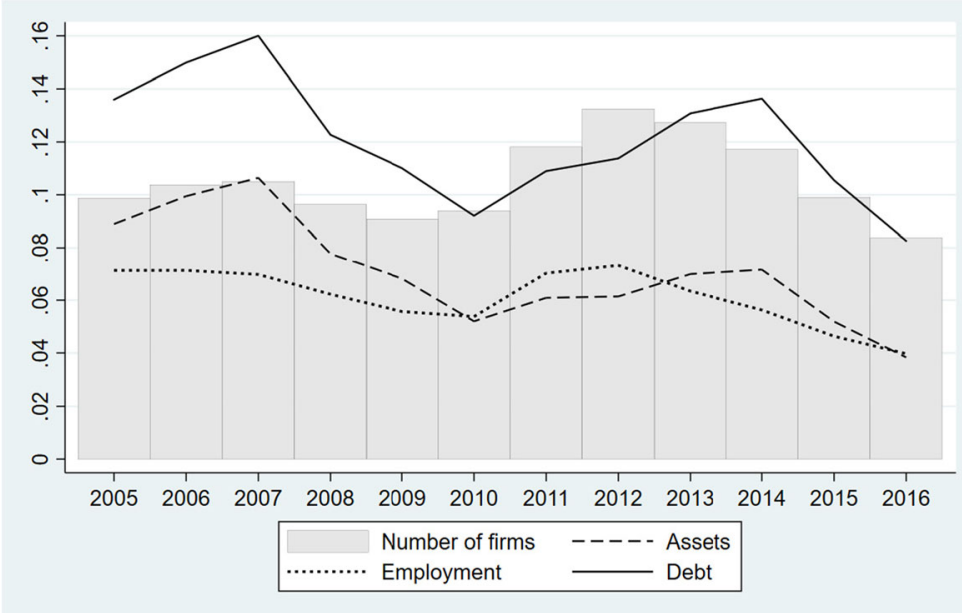

\subsection{Industry productivity and the share of zombie firms}

As discussed in Section 2, zombie firms tend to hinder competition and the efficient allocation of resources, thus generating lower (aggregate) productivity growth. Figure 6 examines the correlation between the ratio of zombie firms and the (weighted) aggregate productivity at the industry-year level (at two-digit NACE Rev. 2 classification). As can be seen, a negative relationship emerges, whereby a higher share of zombies in an industry is associated with a below-average industry productivity performance. According to Table 2, a $1 \%$ decline in the share of zombie firms entails a $0.5 \%$ (3.1\%) rise in the level of industry TFP (labour productivity).

In a well-functioning market economy, the Schumpeterian "creative destruction" forces poorly performing firms to restructure or exit the market. As a consequence, the productivity gap between frontier and zombie firms is expected to narrow rather than widen, by elimination of presumably the worst performing zombies. However, rather than zombie firms catchingup the technological frontier, Fig. 7 shows a persistent (and widening) productivity gap. The technological frontier is given by those firms at the top 5\% in terms of productivity within each industry in each year. Specifically, zombie firms have become relatively less productive, with their TFP decreasing at an average annual rate of $1.0 \%$, compared with TFP gains of $0.5 \%$ per annum for non-zombie firms, which results in a divergence of the productivity gap of 1.5 percentage points per annum. This divergence process is less pronounced in the case of labour productivity, at 0.7 percentage points. Regarding the productivity gap between frontier
Fig. 3 Share of zombie firms by size (employment). Notes: Size class is defined by the number of employees. Pooled yearly values, 2005-2016

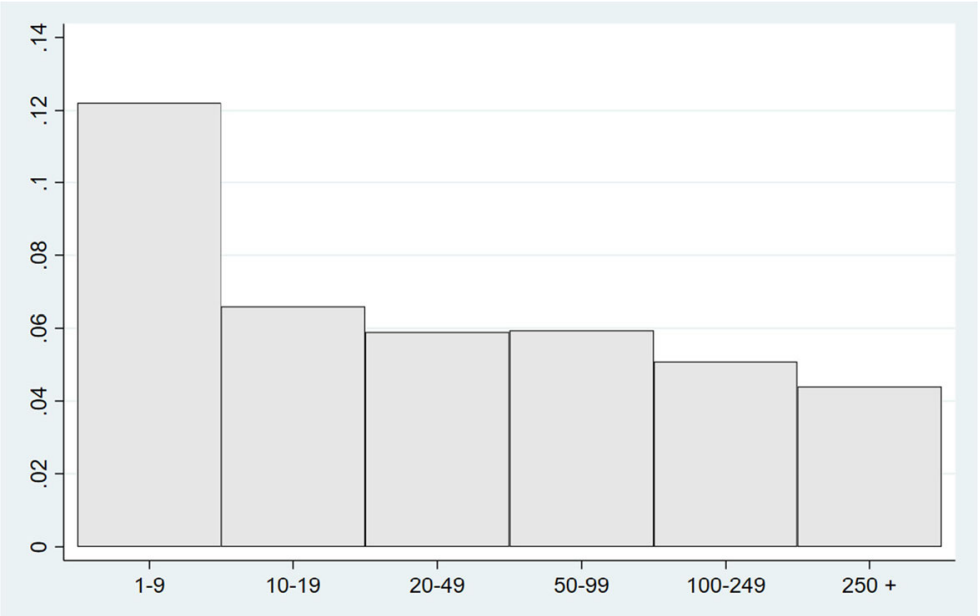


Fig. 4 Share of zombie firms by industry, 2005-2016. Note: The corresponding values by manufacturing industry are given in Table 11

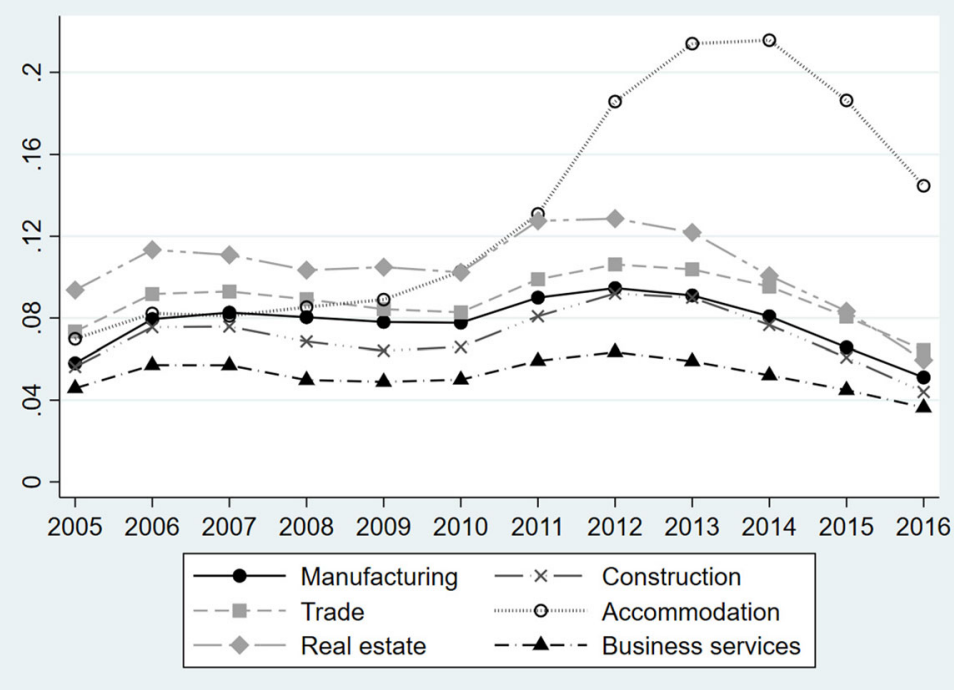

and zombie firms, as can be seen in Fig. 7, it also tends to widen over the period, at 0.9 and 1.0 percentage points per annum, on average, in the TFP and labour productivity cases, respectively.

Given that the presence of zombie firms is across the board and the productivity gap between frontier and zombie firms does not narrow, there may be significant barriers to restructuring or exit. According to Borio and Hofmann (2017) and Banerjee and Hofmann (2018), the ratcheting-down in the level of interest rates during the Great Recession may also have reduced the financial pressure on zombies. What happens when firms become zombies is then the next issue.

\subsection{The dynamics of zombie firms}

Becoming a zombie is presumably not just a consequence of a stroke of misfortune; rather, it is likely to be the result of a persistent and continuous process of declining firm performance (the shadow of death effect; Carreira \& Teixeira, 2011). Figure 8 shows the pattern of some key variables before and after the year in which a firm is classified as zombie $(t=0)$. As can be seen, there is a continuing deterioration in the economic and financial situation prior to $t=0$. These firms also perform poorly on return-on-assets and leverage as time goes by, and there is a declining trend either in terms of
Fig. 5 Productivity distribution of zombie and non-zombie firms. Notes: Kernel density estimation. Total factor productivity and labour productivity are defined as the log deviation from industryyear mean. Variables were winsorised at the 1st and 99th percentiles. Pooled yearly values, 2005-2016

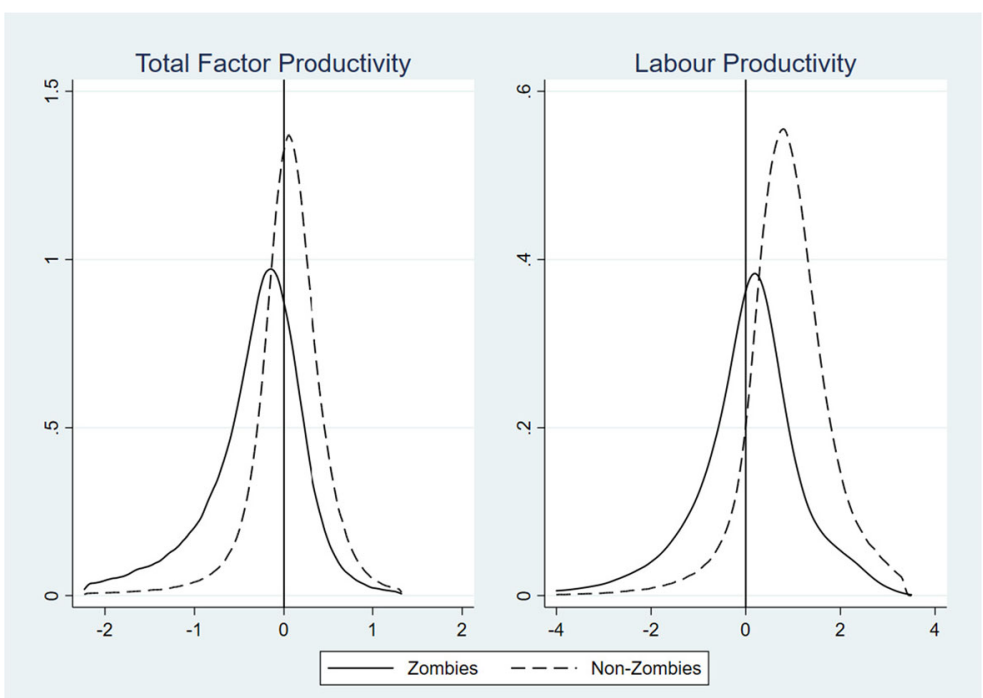


Table 1 Descriptive statistics of zombie and non-zombie firms

\begin{tabular}{|c|c|c|c|c|c|}
\hline & Mean & S.D. & 25PCTL & 50PCTL & 75PCTL \\
\hline \multicolumn{6}{|l|}{ a) Non-zombie firms } \\
\hline TFP (deviation) & 0.04 & 0.48 & -0.14 & 0.06 & 0.27 \\
\hline Labour productivity (deviation) & 0.36 & 2.87 & 0.35 & 0.85 & 1.38 \\
\hline Number of employees & 10.96 & 19.40 & 3 & 5 & 10 \\
\hline Production & 633.16 & 1724.42 & 72.28 & 157.65 & 404.38 \\
\hline GVA & 250.85 & 594.99 & 35.11 & 77.15 & 190.23 \\
\hline EBITDA & 121.86 & 1818.63 & 2.26 & 14.85 & 50.03 \\
\hline Assets & 1109.83 & 3112.46 & 90.71 & 233.54 & 686.09 \\
\hline Debt & 713.66 & 2011.33 & 57.46 & 155.51 & 448.82 \\
\hline \multicolumn{6}{|l|}{ b) Zombie firms } \\
\hline TFP (deviation) & -0.37 & 0.69 & -0.63 & -0.25 & 0.03 \\
\hline Labour productivity (deviation) & -3.09 & 5.68 & -3.61 & -0.21 & 0.49 \\
\hline Number of employees & 6.99 & 13.54 & 3 & 4 & 6 \\
\hline Production & 259.52 & 1029.18 & 24.22 & 56.70 & 136.57 \\
\hline GVA & 63.94 & 269.68 & 0.35 & 15.40 & 43.84 \\
\hline EBITDA & -55.22 & 542.66 & -35.43 & -15.71 & -5.24 \\
\hline Assets & 787.56 & 2666.58 & 44.09 & 128.40 & 387.31 \\
\hline Debt & 849.94 & 2231.79 & 101.30 & 213.94 & 517.81 \\
\hline
\end{tabular}

Notes: Total factor productivity (TFP) and labour productivity are the log deviation from the industry-year mean. The TFP is the log difference between output and the weighted sum of inputs. Labour productivity is the log of GVA per worker. Production is the sales of goods and services, adjusted for changes in inventory of final goods, self-consumption of own production and other operating revenues. GVA and EBITDA are the real gross value added and earnings before interest, taxes, depreciation and amortisation, respectively. Assets and debt are the book value of total (net) assets and total debt. Monetary variables are in $10^{3}$ Euros. All variables were winsorised at the 1 st and 99th percentiles. S.D. denotes the standard deviation. The three last columns of the table indicate the 25, 50 and 75 percentiles. Pooled yearly values, 2004-2017

investment rate or employment growth. On the whole, there is therefore a strong indication that zombie firms

suffer intrinsic economic problems and not only temporary financial constraints.
Fig. 6 Correlation between industry productivity and the share of zombie firms. Notes: Each dot reports industry productivity and zombies share at the industry-year level, at twodigit NACE Rev.2 level, 20052016. Industry total factor productivity (TFP) and industry labour productivity are defined as the log deviation from the year mean
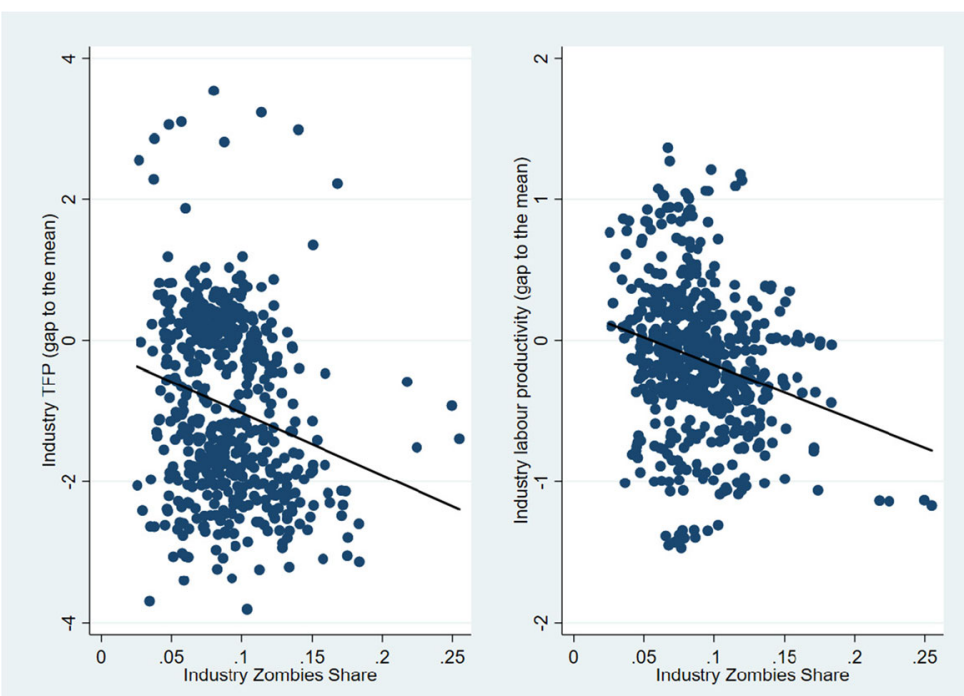
Table 2 Industry productivity and the share of zombie firms

\begin{tabular}{lll}
\hline Variables & Industry TFP & $\begin{array}{l}\text { Industry labour } \\
\text { productivity }\end{array}$ \\
\hline $\begin{array}{l}\text { Industry zombies } \\
\text { share }\end{array}$ & $-0.540 * * *$ & $-3.118^{* * *}(0.099)$ \\
Industry dummies & Yes & Yes \\
Year dummies & Yes & Yes \\
$R^{2}$ & 0.976 & 0.994 \\
No. of observations & 552 & 552
\end{tabular}

Notes: OLS regression of $(\log )$ aggregate productivity on $(\log )$ zombies shares at industry-year level (two-digit NACE Rev. 2 classification). Standard errors are given in parentheses. ***Statistical significance at the 0.01 level

Poorly performing firms should be compelled to restructure or exit in a well-functioning market economy. However, forbearance lending by banks and other creditors may allow zombie firms to continue in such status as time goes by. Actually, as can be seen in Fig. 9, the probability of non-transition of a zombie firm is on average $69 \%$ over the period. This probability rises from $65 \%$ in 2007 to $77 \%$ in 2010 and then it stabilises around the average during the economic recovery. On average, $74 \%$ of zombie firms remain in the same status in the end of second year after having been flagged as zombie and a quarter are still alive as zombie by the end of the fourth year (Table 3). Moreover, firms flagged as zombie during the crisis period (2008-2013) are more likely to stay in this status than those that have become zombies before the crisis. In any event, the likelihood of staying in the zombie status is high, an indication that significant barriers to exit or restructuring are present.

Table 4 provides the transition rates between $t-\tau$ and $t$. More specifically, we compute for four distinct periods-2005-2008 (pre-crisis), 2008-2011 (international financial crisis), 2011-2014 (budgetary crisis) and 2014-2017 (recovery) - the fraction of zombie firms in year $t-\tau$ that remain zombies in $t$, and the corresponding fraction of those that restructure or die between $t-\tau$ and $t$. Clearly, it is confirmed that zombie firms are entrenched. Indeed, only a fraction of zombie firms at $t-\tau$ have switched to non-zombie status (i.e. recovered or exited) over a 3-year time span. For example, about $27 \%$ of zombie firms in 2005 remained zombies in the subsequent 3 -year interval, while over $49 \%$ and $24 \%$ have restructured and exited, respectively. Apparently, the rise of the share of zombies during the crisis period (in Fig. 2), mirrored in the increase of the transition rate of remaining as a zombie in the following year by 12 percentage points (in Fig. 9), was due to a clear reduction in the recovery rate by a notorious 11 percentage points, without a corresponding increase in the exit rate, as shown in row 3 of Table 4 .

Zombie firms require a period of approximately 3 years and 6 months to exit and 3 years and 2 months to recover, which can again be interpreted as evidence in
Fig. 7 Productivity gap across frontier, zombie and non-zombie firms. Notes: Zombies and nonzombies lines give the average (log) productivity weighted by firm's output in the TFP case and by firm's employment in the labour productivity case within each (two-digit) industry. The global frontier is defined as the average (log) productivity of the $5 \%$ most productive firms within each industry. Unweighted averages across industries normalised to 0 for the frontier in the starting year

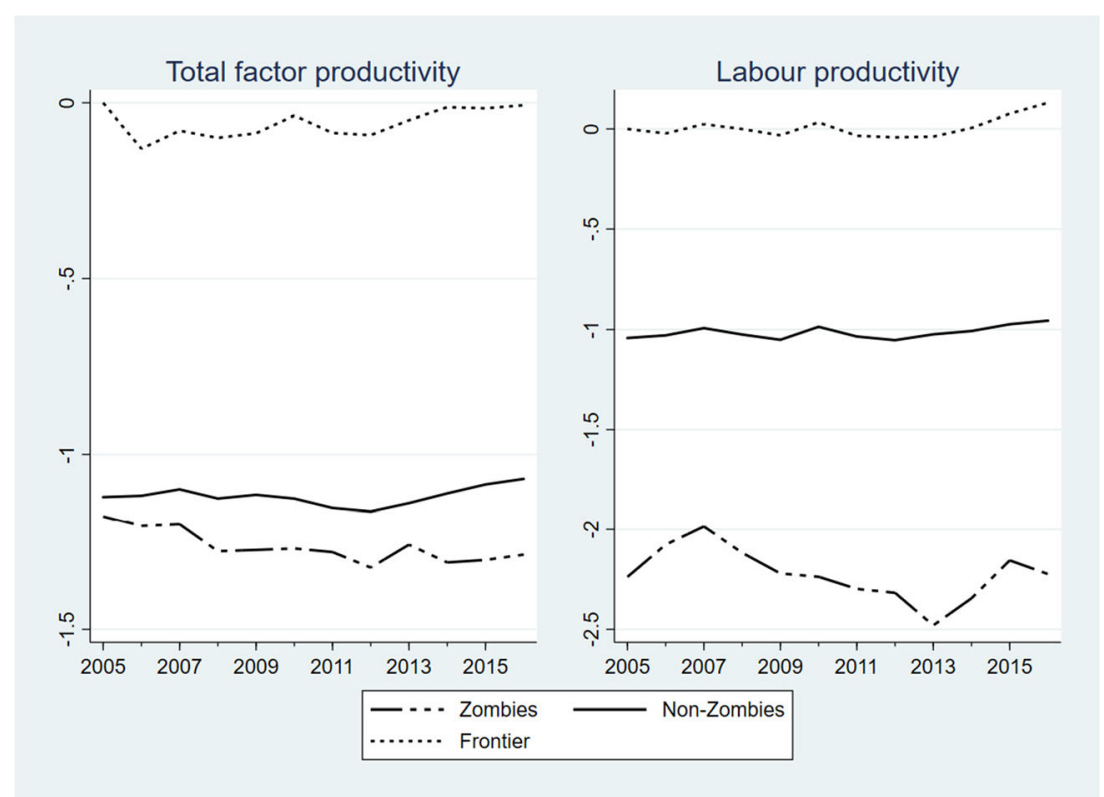




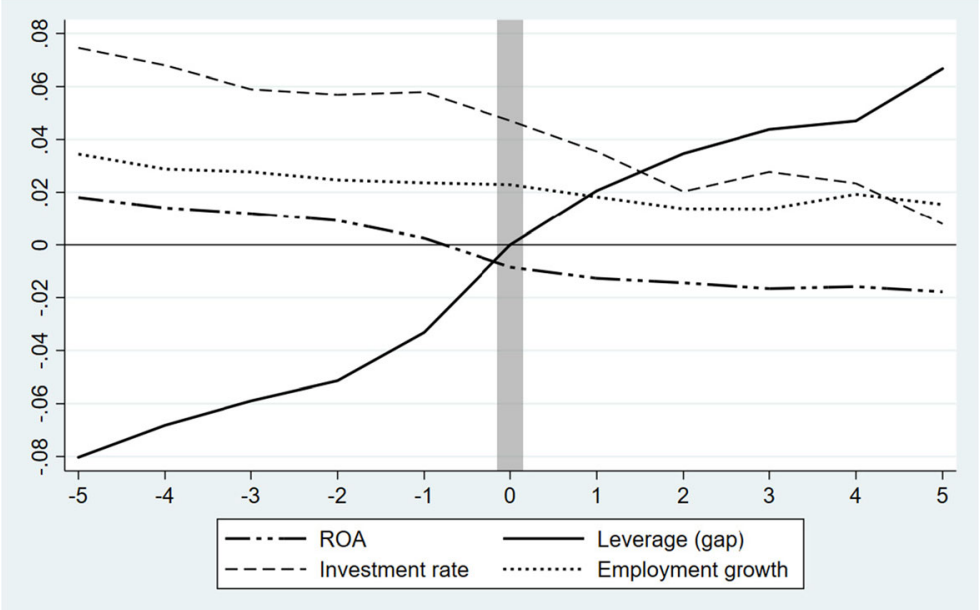

Fig. 8 Firm performance through time. Notes: The horizontal axis refers to years and $t=0$ denotes the year in which a firm is classified as zombie. ROA (return-on-assets) and leverage are measured as EBITDA and the book debt over total assets, respectively. Investment rate is calculated as the ratio of the change in capital to the average total assets in $t$ and $t-1$. The employment

favour of high barriers to restructuring and exiting (Table 5). In the construction industry, for example, the average duration of zombie firms that exited is 3.3 years; in accommodation is 3.7 years. For those that do recovery, the duration is 3.1 and 3.2 years, respectively.

\subsection{The determinants of recovery and exit of zombie} firms

We now investigate the determinants of zombie firm transitions into different destinations within a multinomial logistic model approach. According with the model of Fig. 1, at each period, a zombie firm can either recover, exit the market or remaining as a growth is measured as the ratio of the change in employment to the average employment in $t$ and $t-1$. Industry-level figures are weighted averages by firm's total assets, except the employment growth that is weighted by firm's employment. The aggregate numbers are unweighted averages across industries. The leverage line indicates the log difference from $t=0$

zombie. The non-transition is coded as 1 , while the transition into the recovery state is coded as 2; exit is coded as 3. Formally, and assuming independent and identically distributed extreme value distributed error terms, the probability that the outcome for individual $i$ in year $t$ is destination $j(j=1,2,3)$, conditional on a vector of variables $X_{\mathrm{i}(\mathrm{t}-1)}$, is given by

$$
p_{\mathrm{itj}}=\operatorname{Pr}\left(Y_{\mathrm{it}}=j\right)=\exp \left(X_{\mathrm{i}(\mathrm{t}-1)}^{\prime} \beta_{\mathrm{j}}\right) / \sum_{l=1}^{3} \exp \left(X_{\mathrm{i}(\mathrm{t}-1)}^{\prime} \beta_{1}\right) .
$$

The explanatory variables $X_{\mathrm{i}(\mathrm{t}-1)}$ are lagged 1 year to avoid the simultaneous bias problem (Fukuda \& Nakamura 2011).
Fig. 9 Resilience across zombie firms (in percentage). Notes: The graph shows the conditional survival probability that a zombie firm remains a zombie in the following year. It is computed as the ratio of the number of surviving zombies in $t+1$ to the number of zombies that have survived up to $t$. Unweighted averages across industries

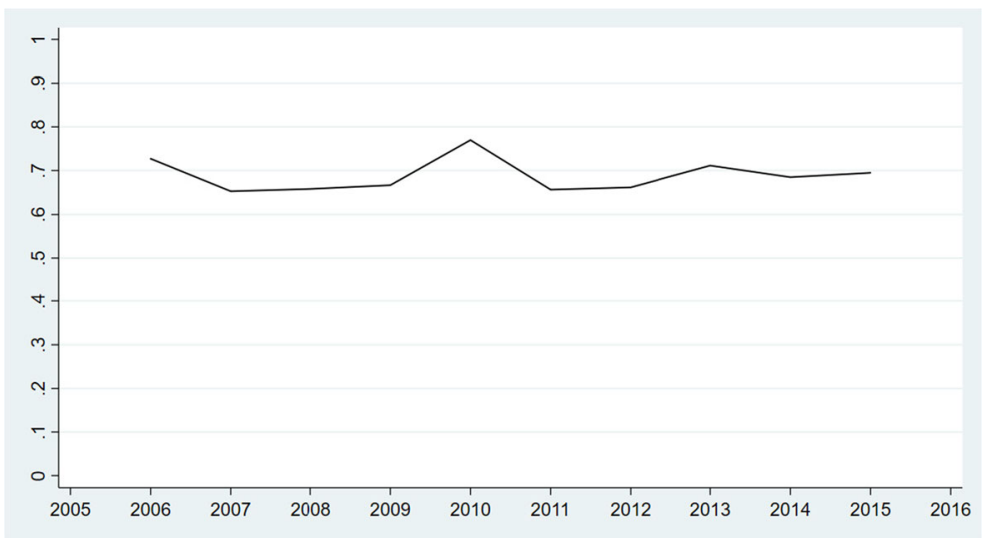


Table 3 Survival rates of zombie firms by year-cohort (in percentage)

\begin{tabular}{|c|c|c|c|c|c|c|c|c|c|c|c|c|}
\hline Cohort: & 2005 & 2006 & 2007 & 2008 & 2009 & 2010 & 2011 & 2012 & 2013 & 2014 & 2015 & 2016 \\
\hline 2005 & 100 & 66.3 & 43.3 & 27.0 & 16.9 & 10.2 & 8.0 & 5.8 & 4.1 & 3.1 & 2.3 & 1.7 \\
\hline 2006 & & 100 & 79.8 & 42.2 & 22.5 & 13.5 & 9.7 & 6.8 & 4.9 & 3.5 & 2.6 & 1.9 \\
\hline 2007 & & & 100 & 75.0 & 37.3 & 19.7 & 13.7 & 9.6 & 6.8 & 4.7 & 3.2 & 2.3 \\
\hline 2008 & & & & 100 & 71.4 & 35.5 & 23.6 & 15.7 & 10.6 & 7.6 & 5.6 & 4.2 \\
\hline 2009 & & & & & 100 & 69.8 & 45.0 & 27.6 & 17.4 & 11.5 & 8.2 & 6.0 \\
\hline 2010 & & & & & & 100 & 80.7 & 46.1 & 28.2 & 17.7 & 11.5 & 7.7 \\
\hline 2011 & & & & & & & 100 & 79.1 & 43.6 & 27.2 & 17.1 & 11.5 \\
\hline 2012 & & & & & & & & 100 & 72.9 & 41.1 & 24.6 & 15.4 \\
\hline 2013 & & & & & & & & & 100 & 72.9 & 40.0 & 23.1 \\
\hline 2014 & & & & & & & & & & 100 & 70.6 & 36.6 \\
\hline 2015 & & & & & & & & & & & 100 & 71.1 \\
\hline
\end{tabular}

Notes: Figures in each row (cohort) report how firms flagged as zombies in a certain year survive over time. They are computed as the ratio of the number of remaining zombie firms to the number of zombie firms in the year in which they became zombies. Unweighted averages across industries

The vector $X_{\mathrm{i}(\mathrm{t}-1)}$ includes three subsets of explanatory variables (available in the SCIE dataset). The first subset of covariates attempts to proxy the operational restructuring of zombie firms and contains the change in the number of employees, the change in assets and the change in productivity, all computed in log differences. Since downsizing and restructuring are the typical strategies adopted by troubled firms, a negative sign for the first two variables and a positive sign for the third variable are expected in the case of the transition into the recovery state. And possibly, the other way around in the case of the transition into exit, although

Table 4 Transition rates (in percentage)

\begin{tabular}{llll}
\hline & Zombie & Recovery & Exit \\
\hline \multirow{4}{*}{ Zombie at 2005 } & \multicolumn{2}{l}{ Transition rates in 2008 } \\
& 27.0 & 48.8 & \\
Zombie at 2008 & Transition rates in 2011 & \\
& 23.7 & 49.0 & 27.3 \\
Zombie at 2011 & Transition rates in 2014 & \\
& 27.2 & 37.8 & 35.0 \\
Zombie at 2014 & Transition rates in 2017 & \\
\hline
\end{tabular}

Notes: Table shows transition rates between years $t-\tau$ and $t$. For example, the first cell on the top left means that $27 \%$ of zombie firms in 2005 remain zombies in 2008. Unweighted averages across industries downsizing may also flag the presence of the shadow of death effect, in which case a negative signal is expected (Carreira \& Teixeira, 2011).

The second subset of covariates comprises the financial variables that are related to external and internal resources and captures the financial restructuring capacity. It includes the leverage ratio and the return-on-assets. Zombie firms with a larger external debt are more difficult to restructure and are at a higher risk of death. Financial restructuring involves a reduction in the debt and a significant modification in its structure. Observe that the leverage ratio only decreases if the debt reduction is greater than the expected reduction in total assets. The expectation is that the leverage ratio has a

Table 5 Average number of years prior to recovery or exit

\begin{tabular}{llll}
\hline Industry & Recovery (a) & Exit (b) & Difference (a-b) \\
\hline Manufacturing & 3.17 & 3.49 & -0.32 \\
Construction & 3.05 & 3.30 & -0.25 \\
Trade & 3.18 & 3.49 & -0.31 \\
Accommodation & 3.22 & 3.67 & -0.45 \\
Real estate & 3.26 & 3.61 & -0.35 \\
Business services & 3.08 & 3.45 & -0.37 \\
Average (unweighted) & 3.16 & 3.50 & $-0,34$ \\
\hline
\end{tabular}

Note: The reported values denote the average number of years a firm stays as zombie prior to recovery or exit 
negative (positive) impact on the probability of recovery (exit). Firms with a higher revenue are expected to face in the future less severe financial constraints than otherwise and, as a consequence, one expects that the return-on-assets variable has a positive (negative) effect on in the probability of recovery (exit) outcome.

Finally, we include four firm-level control variables: zombie duration, firm age, employment and assets. To capture the external environment, industry and year dummies are also included in the regressions. The restructuring of firms that have had long periods of economic and financial trouble is rather challenging. However, this interval can also be interpreted as the time required to implement a restructuring strategy. As a matter of fact, it is expected that zombie firms recover or exit as time goes by, since only forbearance lending by banks and other creditors allows these firms to stay in zombie status for a long time. The effect of (employment and assets) size and age on the recovery of firms can be twofold as well. On the one hand, larger and older firms have more resources and higher managerial ability to restructure; on the other, due the presence of vested interests, inertia tend to be higher, making these firms increasingly ill-suited to deal with a changing environment. Therefore, although their effects should be controlled for, either sign is expected for these variables.

Table 6 presents the results of the multinomial logit regression with three zombie destinationscontinuing (the base category), recovery and exit - with the descriptive statistics and the correlation matrix of covariates given in Tables 14 and 15 in Appendix, respectively. Two specifications of the model are reported: model 1, with TFP as the selected productivity measure, and model 2 , with labour productivity. In both specifications, the null hypothesis that all coefficients are jointly equal to zero is rejected at the 0.01 level of significance (the Wald test at the bottom of the table). Given the reference category, the sign of each coefficient can be interpreted as the effectiveness of each explanatory variable in the transition into recovery or exit.

The change in assets coefficient in recovery category for both models - columns 1 and 3 of the Table 6-is significantly negative as expected. In particular, all else constant, a one-unit decrease in $\Delta \log$ Assets (that we assume as a consequence of a restructuring process) results in an increase in relative odds of recovery vis-àvis continuing zombie of $5.3(10.2) \%$ (i.e. $e^{-0.054}-1=$ -0.053 and $e^{-0.108}-1=-0.102$, respectively). ${ }^{11}$ The change in the number of employees coefficient is only significantly negative in the model 2 . In the case of exit, the change in assets and change in the number of employees coefficients are both negative: the odds ratio of $\Delta$ Log Assets ( $\Delta$ Log Employment) decreases by 64.8 and $62.3 \%$ (38.9 and 37.9\%) in models 1 and 2, respectively. In this case, as suggested by the model in Fig. 1, we may have the presence of the shadow of death effect or just the effect of unsuccessful restructuring. In any event, what is certain is that the probability of continuing zombie decreases with downsizing.

As expected, the coefficient on the change in productivity is positive in columns 1 and 3 and negative in columns 2 and 4 . For example, $\triangle \log T F P$ has an odds ratio of $1.456\left(=e^{0.376}\right)$, suggesting that a one-unit increase in the TFP change makes the outcome of recovery $45.6 \%$ more likely, ceteris paribus. In turn, the relative risk of exit vis-à-vis continuing zombie decreases by $28.2 \%\left(=e^{-0.331}-1=-0.282\right)$. In short, technological restructuring seems to be an effective way to promote recovery of troubled firms, while it reduces the likelihood of exit.

Regarding the financial restructuring capacity, as expected, the Log Leverage (Log Return-on-assets) coefficients are significantly negative (positive) in columns 1 and 3, and conversely in columns 2 and 4. For example, in the case of the model 1 , a one-unit increase in leverage results in a reduction in the relative odds of recover to continuing zombie of $46.2 \%\left(=e^{-0.620}-1=\right.$ $-0.462)$, and a one-unit increase in return-on-assets leads to an increase in the relative odds of $6.4 \%$ $\left(=e^{0.062}-1=0.064\right)$. Firms that reduce their debt at a faster rate than the (expected) asset reduction are more likely to recover and less risk of exit. By contrast, rising revenues are associated with recovery (and lower probability of exit).

The Zombie duration coefficient is significantly positive in all columns. In particular, the relative odds ratio of recovery relative to continuing zombie is 1.217 $\left(=e^{0.197}\right)$, while the respective odds in the case of exit

\footnotetext{
11 The odds ratios in logit regression can be interpreted as the effect of a one unit of change in $x_{i(t-1)}$ in the predicted relative-risk ratio with the other covariates held constant, that is: $\frac{\operatorname{Pr}\left(Y_{\mathrm{it}}=j \mid X_{\mathrm{i}(\mathrm{t}-1)}+1\right) /\left[1-\operatorname{Pr}\left(Y_{\mathrm{it}}=j \mid X_{\mathrm{i}(\mathrm{t}-1)}+1\right)\right]}{\operatorname{Pr}\left(Y_{\mathrm{it}}=j \mid X_{\mathrm{i}(\mathrm{t}-1)}\right) /\left[1-\operatorname{Pr}\left(Y_{\mathrm{it}}=j \mid X_{\mathrm{i}(\mathrm{t}-1)}\right)\right]}$.
} 
Table 6 Multinomial logit regression

\begin{tabular}{|c|c|c|c|c|}
\hline \multirow[t]{2}{*}{ Variables } & \multicolumn{2}{|l|}{ Model 1: TFP } & \multicolumn{2}{|c|}{ Model 2: labour productivity } \\
\hline & $\begin{array}{l}\text { Recovery } \\
\text { (1) }\end{array}$ & $\begin{array}{l}\text { Exit } \\
(2)\end{array}$ & $\begin{array}{l}\text { Recovery } \\
\text { (3) }\end{array}$ & $\begin{array}{l}\text { Exit } \\
(4)\end{array}$ \\
\hline$\Delta \log$ Assets & $-0.054 * * *(0.017)$ & $-1.043 * * *(0.017)$ & $-0.108 * * *(0.017)$ & $-0.976 * * *(0.017)$ \\
\hline$\Delta \log$ Employment & $-0.018(0.017)$ & $-0.492 * * *(0.019)$ & $-0.067 * * *(0.016)$ & $-0.476 * * *(0.019)$ \\
\hline$\Delta \log$ Productivity & $0.376 * * *(0.012)$ & $-0.331 * * *(0.013)$ & $0.019 * * *(0.001)$ & $-0.016^{* * *}(0.001)$ \\
\hline Log Leverage & $-0.620 * * *(0.016)$ & $0.242 * * *(0.016)$ & $-0.611 * * *(0.016)$ & $0.243 * * *(0.016)$ \\
\hline Log Return-on-assets & $0.062 * * *(0.004)$ & $-0.095 * * *(0.007)$ & $0.070 * * *(0.004)$ & $-0.108 * * *(0.007)$ \\
\hline Log Zombie duration & $0.222 * * *(0.013)$ & $0.691 * * *(0.014)$ & $0.248 * * *(0.013)$ & $0.666^{* * *}(0.014)$ \\
\hline Log Age & $-0.019(0.015)$ & $-1.211 * * *(0.021)$ & $-0.020(0.015)$ & $-1.201 * * *(0.020)$ \\
\hline Log Employment & $0.113 * * *(0.008)$ & $-0.164 * * *(0.011)$ & $0.114 * * *(0.008)$ & $-0.182 * * *(0.011)$ \\
\hline Log Assets & $-0.106^{* * *}(0.005)$ & $0.049 * * *(0.007)$ & $-0.108 * * *(0.005)$ & $0.058 * * *(0.007)$ \\
\hline \multicolumn{5}{|l|}{ Industry dummy: } \\
\hline Construction & $0.187 * * *(0.020)$ & $0.074 * * *(0.025)$ & $0.176 * * *(0.020)$ & $0.103 * * *(0.025)$ \\
\hline Trade & $-0.006(0.018)$ & $-0.206 * * *(0.022)$ & $-0.008(0.018)$ & $-0.220 * * *(0.022)$ \\
\hline Accommodation & $-0.013(0.022)$ & $-0.660 * * *(0.027)$ & $-0.011(0.022)$ & $-0.669 * * *(0.027)$ \\
\hline Real estate & $0.330 * * *(0.035)$ & $-0.473 * * *(0.048)$ & $0.324 * * *(0.035)$ & $-0.486 * * *(0.048)$ \\
\hline Business services & $0.326 * * *(0.023)$ & $-0.315 * * *(0.030)$ & $0.319 * * *(0.023)$ & $-0.284 * * *(0.030)$ \\
\hline \multicolumn{5}{|l|}{ Year dummy: } \\
\hline 2006 & $-0.368 * * *(0.029)$ & $-0.486 * * *(0.042)$ & $-0.373 * * *(0.029)$ & $-0.498 * * *(0.042)$ \\
\hline 2007 & $-0.136 * * *(0.028)$ & $-0.014(0.039)$ & $-0.149 * * *(0.028)$ & $-0.011(0.039)$ \\
\hline 2008 & $0.063 * *(0.029)$ & $0.079 * *(0.040)$ & $0.037(0.028)$ & $0.088 * *(0.040)$ \\
\hline 2009 & $0.142 * * *(0.029)$ & $0.039(0.041)$ & $0.123 * * *(0.029)$ & $0.039(0.041)$ \\
\hline 2010 & $-0.621 * * *(0.032)$ & $-0.289 * * *(0.041)$ & $-0.635 * * *(0.032)$ & $-0.289 * * *(0.041)$ \\
\hline 2011 & $-0.496 * * *(0.030)$ & $0.206^{* * *}(0.038)$ & $-0.523 * * *(0.030)$ & $0.217 * * *(0.038)$ \\
\hline 2012 & $-0.164 * * *(0.030)$ & $0.242 * * *(0.038)$ & $-0.189 * * *(0.030)$ & $0.249 * * *(0.038)$ \\
\hline 2013 & $-0.107 * * *(0.030)$ & $0.174 * * *(0.040)$ & $-0.111 * * *(0.030)$ & $0.167 * * *(0.040)$ \\
\hline 2014 & $0.069 * *(0.030)$ & $0.073 *(0.041)$ & $0.066 * *(0.030)$ & $0.062(0.041)$ \\
\hline 2015 & $0.138 * * *(0.032)$ & $0.120 * * *(0.043)$ & $0.137 * * *(0.032)$ & $0.108 * *(0.043)$ \\
\hline 2016 & $-2.438 * * *(0.027)$ & $-0.116^{* * *}(0.044)$ & $-2.436 * * *(0.027)$ & $-0.138 * * *(0.044)$ \\
\hline Constant & $0.803 * * *(0.083)$ & $-0.805 * * *(0.119)$ & $0.883 * * *(0.083)$ & $-0.966 * * *(0.119)$ \\
\hline No. of observations & & 195,155 & & 195,155 \\
\hline Wald chi-square & & $5538154 * * *$ & & $5927285^{* * * *}$ \\
\hline Log pseudolikelihood & & -149767 & & -150578 \\
\hline Pseudo $R^{2}$ & & 0.1011 & & 0.0962 \\
\hline
\end{tabular}

Notes: Multinomial logit model. The base category for the dependent variable is the continuing zombie status. The variables were winsorised at the 1 st and 99 th percentiles. Firm-cluster robust standard errors are given in parentheses

$* * *, * *$ and $*$ Statistical significance at the $0.01,0.05$ and 0.10 levels, respectively

is $2.051\left(=e^{0.718}\right)$. That is, the chance of a firm remaining as a zombie decreases, an expected effect related to the fact that most zombies stay alive only due to forbearance lending by banks and other creditors and information asymmetry decreases over time.
The effect of firm size is less straightforward. Measured by the number of employees (Log Employment), it can be seen that the larger is the firm, the higher (lower) will be the likelihood of transition into recovery (exit). Conversely, the Log Assets variable coefficient is 
significantly negative and positive in the recover and exit cases, respectively. Firm age coefficient is positive (negative), suggesting that transitions into recovery (exit) are more (less) likely for older firms. Apparently, larger (measured by the number of employees) and older firms have more resources and higher managerial ability to restructure. Managers of these firms have also substantial power to turn the tables on hostile creditors because of the adverse consequences of their failure for creditors and perhaps the whole financial system (vulgo: "too big to fail"; e.g. Moosa, 2010).

Finally, regarding the external environment, the year dummies seem to suggest that the relative probability of recovery is lower during the crisis, while the probability of exit is higher, a result that is in line with transition rates found in Table 4. The relative odds of recover are $39.1 \%$ and $38.5 \%$ higher for real estate and business services firms, respectively, than for manufacturing firms (the benchmark), while the respective odds of exit are $37.7 \%$ and $27.0 \%$ lower. Remarkably, in accommodation industry, the relative probability of exit is $48.3 \%$ less likely.

\section{Robustness checks}

This section tests the robustness of our results (i) by employing three alternative definitions of zombie firms, (ii) by testing slight variations in our own definition and (iii) by using an ordered logit model. Regarding the first test, three alternative definitions were considered in Table 7: the interest coverage ratio proposed by McGowan et al. (2017a), in columns (2) and (6); the evergreen lending version proposed by Shen and Chen (2017), in columns (3) and (7); and the original definition of Schivardi et al. (2017), in columns (4) and (8). Although the magnitude of the coefficients given in Table 16 varies somewhat, our results are qualitatively robust. Moreover, there are no significant changes in both the sign and the statistical significance of the average marginal effects of key explanatory variables on recovery and exit transition probabilities-for example, on average, a one-unit increase in the $\triangle \log T F P$ makes the outcome of recovery (exit) 1.8 (2.2) percentage points more (less) likely in the interest coverage ratio definition (in column (2) of Table 7), compared with 3.7 (4.4) and 6.4 (3.9) percentage points in the definition of Schivardi et al. (2017) and our own definition, respectively. Note that for each variable, the marginal effects add up to zero because probabilities add up to one. The only notable exception is the case of the average marginal effect of $\Delta \log$ Employment on the recovery likelihood, where we found an opposite direction. The main findings therefore remain valid across definitions.

Given the methodological issues involved in identifying zombie firms, we confirm that our main results hold when using slight variations in our own definition. To this end, as a second robustness check, we reran our multinomial logit regression assuming three definition variants: (i) return-on-assets lower than the interest rate on loan operations to enterprises (annual average), rather than the Euribor 12-month interest rate; (ii) leverage above the industry average (or $75^{\text {th }}$ percentile) in the low return-on-assets exiting group; and (iii) 10-year limit used by McGowan et al. (2017a). The results largely confirm those in Table 6 , with again the magnitude of the coefficients broadly in line. These results are available from the authors on request.

Our final robustness test implements an ordered logit model. From the perspective of a firm/entrepreneur, recovery is preferred to remaining as a zombie, and persistence in the zombie status is preferred to exit. Accordingly, we define a three-point scale from the lowest to the highest level (i.e. $1=$ exit; 2 = remaining as a zombie; and $3=$ recovery), to yield the following ordered logistic regression model in which we also examine the relevant transitions:

$p_{\mathrm{itj}}=\operatorname{Pr}\left(Y_{\mathrm{it}}=j\right)=\operatorname{Pr}\left(\kappa_{\mathrm{j}-1}<X_{\mathrm{i}(\mathrm{t}-1)}^{\prime} \beta \leq \kappa_{\mathrm{j}}\right)$,

where $\kappa_{\mathrm{j}}$ denotes the cutpoint for outcome $j$, with $j=1$, 2,3 and $\kappa_{1}<\kappa_{2}<\kappa_{3}$. Table 8 reports the average marginal effects from the ordered logit regression (the corresponding regression results are given in Tables 17 in Appendix). It can be seen that in the case of recovery and exit, the marginal effects from the two models (multinomial and ordered) are indeed very similar (that is, with the same sign and statistical significance except in very few cases), a further indication that our findings are robust to different types of experimentation. 


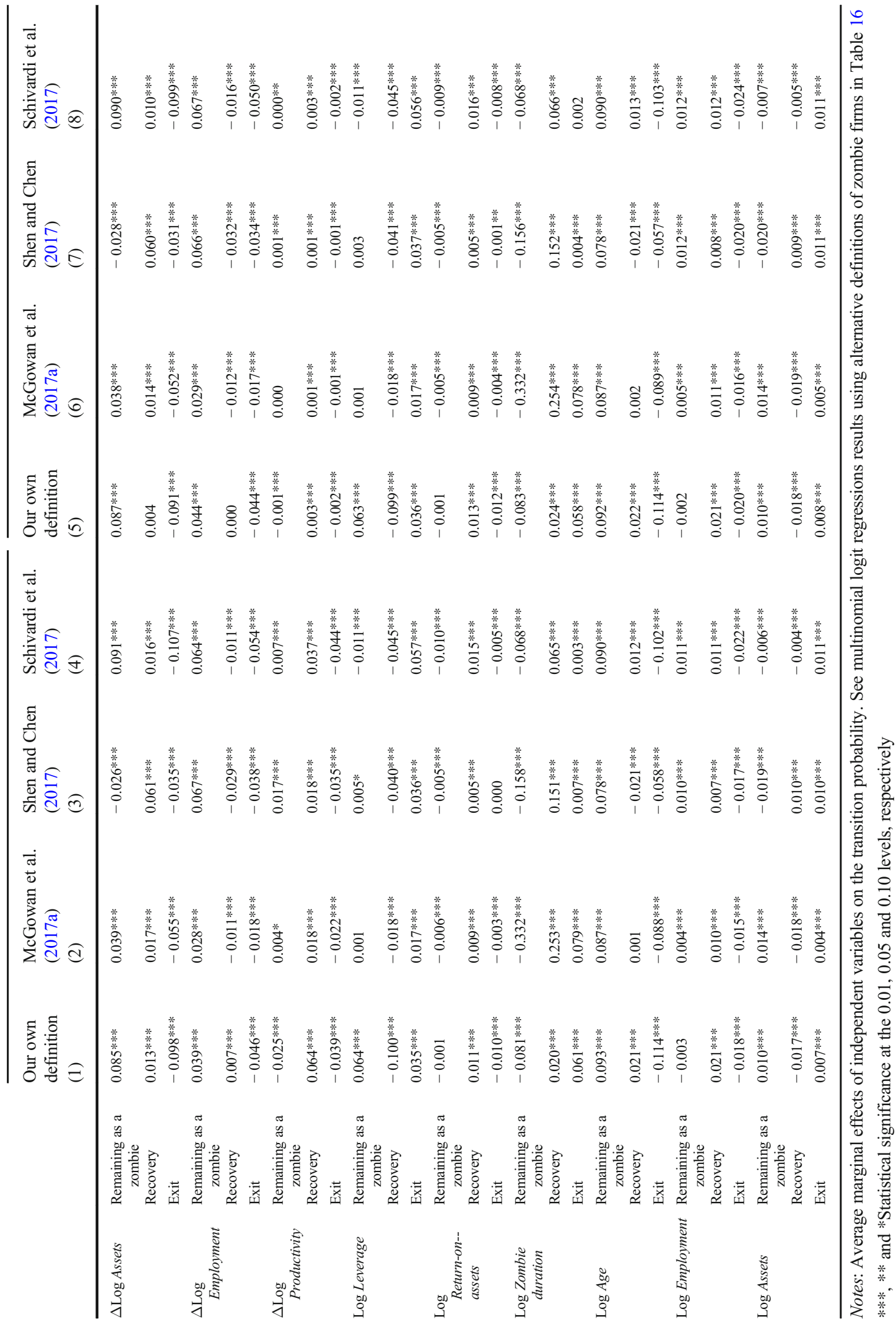


Table 8 Robustness: average marginal effects from multinomial logit regression vs. ordered logit regression

\begin{tabular}{|c|c|c|c|c|c|}
\hline \multirow[t]{2}{*}{ Variable } & \multirow[t]{2}{*}{ Transition } & \multicolumn{2}{|c|}{ Model 1: TFP } & \multicolumn{2}{|c|}{ Model 2: labour productivity } \\
\hline & & $\begin{array}{l}\text { Multinomial } \\
\text { (1) }\end{array}$ & $\begin{array}{l}\text { Ordered } \\
\text { (2) }\end{array}$ & $\begin{array}{l}\text { Multinomial } \\
\text { (3) }\end{array}$ & $\begin{array}{l}\text { Ordered } \\
\text { (4) }\end{array}$ \\
\hline \multirow[t]{3}{*}{$\Delta \log$ Assets } & Exit & $-0.098 * * *$ & $-0.063 * * *$ & $-0.091 * * *$ & $-0.056^{* * *}$ \\
\hline & Remaining as a zombie & $0.085^{* * *}$ & $-0.031 * * *$ & $0.087 * * *$ & $-0.028 * * *$ \\
\hline & Recovery & $0.013 * * *$ & $0.094 * * *$ & 0.004 & $0.084 * * *$ \\
\hline \multirow[t]{3}{*}{$\Delta$ Log Employment } & Exit & $-0.046 * * *$ & $-0.028 * * *$ & $-0.044 * * *$ & $-0.024 * * *$ \\
\hline & Remaining as a zombie & $0.039 * * *$ & $-0.014 * * *$ & $0.044 * * *$ & $-0.012 * * *$ \\
\hline & Recovery & $0.007 * * *$ & $0.042 * * *$ & 0.000 & $0.036 * * *$ \\
\hline \multirow[t]{3}{*}{$\Delta$ Log Productivity } & Exit & $-0.039 * * *$ & $-0.045 * * *$ & $-0.002 * * *$ & $-0.002 * * *$ \\
\hline & Remaining as a zombie & $-0.025 * * *$ & $-0.022 * * *$ & $-0.001 * * *$ & $-0.001 * * *$ \\
\hline & Recovery & $0.064 * * *$ & $0.067 * * *$ & $0.003 * * *$ & $0.003 * * *$ \\
\hline \multirow[t]{3}{*}{ Log Leverage } & Exit & $0.035 * * *$ & $0.060 * * *$ & $0.036 * * *$ & $0.061 * * *$ \\
\hline & Remaining as a zombie & $0.064 * * *$ & $0.030 * * *$ & $0.063 * * *$ & $0.030 * * *$ \\
\hline & Recovery & $-0.100 * * *$ & $-0.090 * * *$ & $-0.099 * * *$ & $-0.091 * * *$ \\
\hline \multirow[t]{3}{*}{ Log Return-on-assets } & Exit & $-0.010 * * *$ & $-0.007 * * *$ & $-0.012 * * *$ & $-0.009 * * *$ \\
\hline & Remaining as a zombie & -0.001 & $-0.004 * * *$ & -0.001 & $-0.004 * * *$ \\
\hline & Recovery & $0.011 * * *$ & $0.011 * * *$ & $0.013 * * *$ & $0.013 * * *$ \\
\hline \multirow[t]{3}{*}{ Log Zombie duration } & Exit & $0.061 * * *$ & $0.010 * * *$ & $0.058 * * *$ & $0.006 * * *$ \\
\hline & Remaining as a zombie & $-0.081 * * *$ & $0.005 * * *$ & $-0.083 * * *$ & $0.003 * * *$ \\
\hline & Recovery & $0.020 * * *$ & $-0.015^{* * *}$ & $0.024 * * *$ & $-0.009 * * *$ \\
\hline \multirow[t]{3}{*}{ Log Age } & Exit & $-0.114 * * *$ & $-0.035 * * *$ & $-0.114 * * *$ & $-0.035^{* * *}$ \\
\hline & Remaining as a zombie & $0.093 * * *$ & $-0.017 * * *$ & $0.092 * * *$ & $-0.017 * * *$ \\
\hline & Recovery & $0.021 * * *$ & $0.052 * * *$ & $0.022 * * *$ & $0.052 * * *$ \\
\hline \multirow[t]{3}{*}{ Log Employment } & Exit & $-0.018 * * *$ & $-0.016^{* * *}$ & $-0.020^{* * *}$ & $-0.018^{* * *}$ \\
\hline & Remaining as a zombie & $-0.003 *$ & $-0.008 * * *$ & -0.002 & $-0.009 * * *$ \\
\hline & Recovery & $0.021 * * *$ & $0.024 * * *$ & $0.021 * * *$ & $0.026 * * *$ \\
\hline \multirow[t]{3}{*}{ Log Assets } & Exit & $0.007 * * *$ & $0.010 * * *$ & $0.008 * * *$ & $0.011 * * *$ \\
\hline & Remaining as a zombie & $0.010^{* * *}$ & $0.005 * * *$ & $0.010 * * *$ & $0.005 * * *$ \\
\hline & Recovery & $-0.017 * * *$ & $-0.015 * * *$ & $-0.018^{* * *}$ & $-0.016^{* * *}$ \\
\hline
\end{tabular}

Notes: Average marginal effects of independent variables on the transition probability. See ordered logit regression results in Table 17 $* * *, * *, *$ Statistical significance at the $0.01,0.05$ and 0.10 levels, respectively

\section{Conclusion}

In the last two decades, the share of zombie firms has widened considerably across developed economies, a phenomenon that is believed to reduce the path of economic growth. Using the population of Portuguese firms in the manufacturing and services industries over the period of 2004-2017, our approach was largely focused on transitions into recovery and exit, as well as on the corresponding determinants.
We confirm that zombies are across the board and that they are significantly less productive than non-zombies. Moreover, industries with higher shares of zombies have lower levels of aggregate productivity. Recovery and exit are therefore expected to generate a higher aggregate productivity growth. Since the probability of transition into recovery and exit is relatively low, there seems to be important barriers to firm mobility. Zombies actually require about 4 years to recover or exit. The 
regression results show in turn that downsizing and restructuring, as well as debt restructuring, are crucial in enhancing recovery of zombie firms.

These findings have important managerial and policy implications for financially distressed firms that are facing the challenges of recovery or exit. In particular, the empirical results support the argument that dealing with weak firms requires a holistic and coordinated strategy, comprising operational and technological restructuring, downsizing and debt restructuring. Governments should therefore formulate an adequate institutional framework to strengthen the selection of zombie firms, especially by discouraging creditors to refinance these firms and by designing more reallocation-friendly insolvency regimes. Restructuring and insolvency involve significant welfare costs, which should be a matter of concern for governments too.

One limitation of our study is the set of variables used as proxies for firm restructuring. Future research should use variables that more accurately measure technological and financing restructuring. Since barriers to restructuring and exit restrain the reduction of the share of resources sunk in zombie firms, research on the role of insolvency regimes on productivity growth should be a high priority too in future research. Further analysis of the legal environment should also be considered, given that an efficient judicial system is crucial in enhancing resource allocation.
Acknowledgements We would like to take this opportunity to thank the anonymous reviewers, and the participants at the Paper Development Workshop (PDW) organised at the University of Bergamo (May 2019) and our discussant, Eleonora Bartoloni, for their helpful comments. We would also like to thank the Guest Editors for their time and effort devoted to the special issue.

Availability of data and material The data used come from the secured access version of the Integrated Business Accounts System (Sistema de Contas Integradas das Empresas, SCIE) supplied by the Portuguese Statistical Office (Instituto Nacional de Estatística, INE) and will be made available upon request from the corresponding author (Carlos Carreira).

Author contribution All authors read and approved the final manuscript.

Funding This work has been funded by the FCT - Fundação para a Ciência e a Tecnologia, I.P., Project ENtRY (PTDC/EGEECO/31117/2017) and CeBER (UIDB/05037/2020) and by the FFMS - Fundação Francisco Manuel dos Santos as part of the project "Financial Constraints, Investment and Firm Dynamics: Lessons from the Portuguese Great Recession and its aftermath".

\section{Declarations}

Conflict of interest The authors declare no competing interests.

\section{Appendix}

See Fig. 10 and Tables 9, 10, 11, 12, 13, 14, 15, 16 and 17.
Fig. 10 Share of zombie firms using alternative definitions. Notes: Share of zombies in terms of the number of firms. The alternative definitions of zombie firms are (i) the interest coverage ratio proposed by McGowan et al. (2017a), (ii) the evergreen lending version proposed by Shen and Chen (2017) and (iii) the original definition of Schivardi et al. (2017). Our own definition is given in the notes to Fig. 2. All definitions include "older than 5 years" criterion

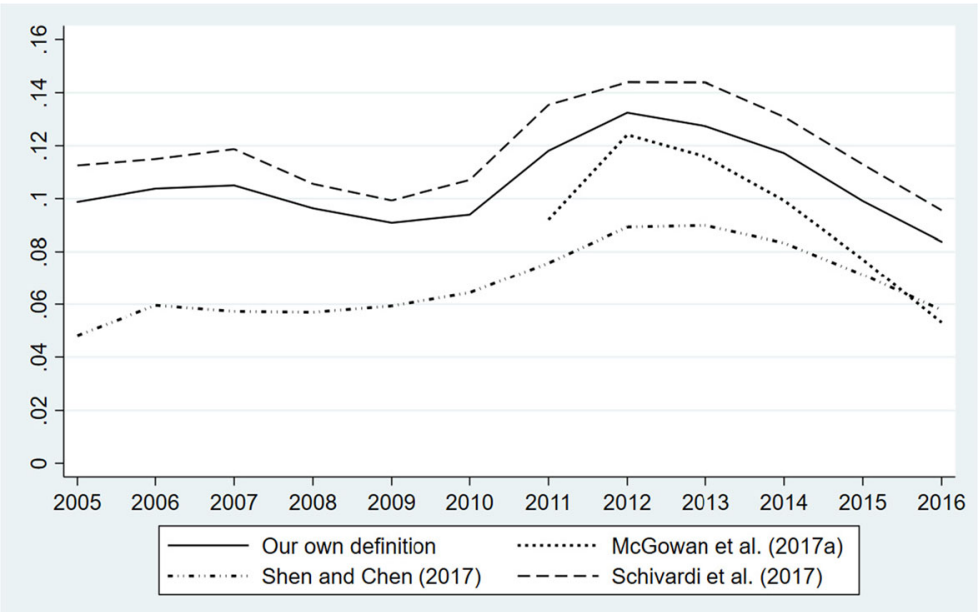


Table 9 Number of firms by industry, 2004-2017

\begin{tabular}{|c|c|c|c|c|c|}
\hline NACE & Industry & Mean & S.D. & Min & Max \\
\hline $10-33$ & MANUFACTURING & 30,614 & 1803 & 28,393 & 32,899 \\
\hline $10-11$ & Food products and beverages & 4866 & 135 & 4557 & 5014 \\
\hline $13-14$ & Textiles and wearing apparel & 5620 & 754 & 4858 & 6899 \\
\hline 15 & Leather and leather products & 1659 & 81 & 1556 & 1795 \\
\hline 16,31 & Wood and wood products; furniture & 4061 & 433 & 3565 & 4610 \\
\hline $17-18$ & Pulp, paper, paper products and publishing & 1697 & 179 & 1464 & 1921 \\
\hline $19-21$ & Chemical and chemical products & 558 & 44 & 518 & 625 \\
\hline $22-23$ & Rubber and plastic products; other non-metallic & 2936 & 304 & 2563 & 3291 \\
\hline $24-25$ & Basic metals and fabricated metal products & 5311 & 192 & 5035 & 5563 \\
\hline $26-27$ & Electronic and electrical equipment & 534 & 35 & 499 & 599 \\
\hline 28 & Machinery and equipment & 928 & 77 & 846 & 1033 \\
\hline $29-30$ & Motor vehicles, trailers and other transport equip. & 490 & 29 & 447 & 532 \\
\hline $32-33$ & Other manufacturing n.e.c. and recycling & 1955 & 98 & 1807 & 2160 \\
\hline $41-43$ & CONSTRUCTION & 26,887 & 3725 & 22,177 & 31,338 \\
\hline $45-47$ & TRADE & 51,462 & 1352 & 49,517 & 53,453 \\
\hline $55-56$ & ACCOMMODATION & 19,977 & 1610 & 17,024 & 23,020 \\
\hline 68 & REAL ESTATE & 4329 & 284 & 3946 & 4772 \\
\hline $62-63,69-82$ & BUSINESS SERVICES & 21,438 & 2144 & 17,767 & 25,009 \\
\hline
\end{tabular}

Notes: Two-digit level NACE-Rev.2 classification. The reported values are computed over the entire period, 2004-2017

Table 10 Tetrachoric correlation across four alternative definitions of zombie firms

\begin{tabular}{llll}
\hline Definition & {$[1]$} & [2] & [3] \\
\hline [1] McGowan et al. (2017a) & 1 & 1 & \\
[2] Shen and Chen (2017) & 0.6753 & 0.8650 & 1 \\
[3] Schivardi et al. (2017) & 0.5990 & 0.9135 & 0.9735 \\
[4] Our own definition & 0.6539 &
\end{tabular}

Notes: See notes to Fig. 10. The correlation coefficient is always statistically significant at the 0.01 level

Table 11 Share of zombie firms by industry (in percentage)

\begin{tabular}{lllllllllllll}
\hline Industry & 2005 & 2006 & 2007 & 2008 & 2009 & 2010 & 2011 & 2012 & 2013 & 2014 & 2015 & 2016 \\
\hline MANUFACTURING & 5.8 & 7.9 & 8.3 & 8.0 & 7.8 & 7.8 & 9.0 & 9.5 & 9.1 & 8.1 & 6.6 & 5.1 \\
Food products and beverages & 6.1 & 7.8 & 7.7 & 7.3 & 7.1 & 7.6 & 9.5 & 11.6 & 12.5 & 12.3 & 10.3 & 8.6 \\
Textiles and wearing apparel & 6.2 & 8.6 & 9.2 & 9.1 & 9.8 & 9.2 & 9.6 & 8.8 & 7.4 & 5.6 & 4.7 & 3.7 \\
Leather and leather products & 4.0 & 5.8 & 5.3 & 4.9 & 4.1 & 3.5 & 3.6 & 3.6 & 3.5 & 3.4 & 3.2 & 2.5 \\
Wood and wood products; furniture & 7.0 & 9.8 & 10.1 & 10.5 & 9.9 & 10.1 & 12.2 & 13.1 & 12.5 & 10.9 & 8.4 & 6.3 \\
Pulp, paper, paper products and publishing & 5.6 & 7.0 & 7.2 & 7.1 & 6.8 & 7.3 & 8.3 & 8.4 & 7.7 & 6.8 & 6.2 & 4.7 \\
Chemical and chemical products & 6.4 & 8.5 & 8.1 & 8.3 & 6.0 & 5.4 & 6.3 & 6.3 & 6.6 & 6.2 & 5.1 & 5.1 \\
Rubber and plastic products; other non-metallic & 6.0 & 8.8 & 9.9 & 10.3 & 9.7 & 10.4 & 12.2 & 13.0 & 12.5 & 10.8 & 8.7 & 6.6 \\
Basic metals and fabricated metal products & 4.8 & 6.6 & 7.0 & 6.4 & 6.0 & 6.1 & 7.5 & 8.2 & 8.1 & 7.3 & 5.5 & 3.9 \\
Electronic and electrical equipment & 6.6 & 8.0 & 8.4 & 6.9 & 7.7 & 6.4 & 7.8 & 6.4 & 5.7 & 6.6 & 6.1 & 4.8 \\
Machinery and equipment & 5.3 & 6.6 & 5.8 & 5.0 & 5.9 & 5.8 & 6.1 & 5.5 & 5.1 & 3.9 & 2.9 & 2.2
\end{tabular}


Table 11 (continued)

\begin{tabular}{|c|c|c|c|c|c|c|c|c|c|c|c|c|}
\hline Industry & 2005 & 2006 & 2007 & 2008 & 2009 & 2010 & 2011 & 2012 & 2013 & 2014 & 2015 & 2016 \\
\hline Motor vehicles, trailers and other transport equipment & 6.1 & 7.9 & 7.7 & 7.7 & 7.4 & 7.8 & 8.1 & 8.8 & 8.4 & 6.7 & 5.1 & 4.0 \\
\hline Other manufacturing n.e.c. and recycling & 5.1 & 7.5 & 8.0 & 7.1 & 6.6 & 5.9 & 6.7 & 6.2 & 6.1 & 5.3 & 4.5 & 3.6 \\
\hline CONSTRUCTION & 5.6 & 7.6 & 7.6 & 6.9 & 6.4 & 6.6 & 8.1 & 9.2 & 9.0 & 7.7 & 6.1 & 4.4 \\
\hline TRADE & 7.3 & 9.2 & 9.3 & 8.9 & 8.4 & 8.3 & 9.9 & 10.6 & 10.4 & 9.5 & 8.1 & 6.4 \\
\hline ACCOMMODATION & 7.0 & 8.2 & 8.1 & 8.5 & 8.9 & 10.3 & 13.1 & 18.6 & 21.4 & 21.6 & 18.6 & 14.5 \\
\hline REAL ESTATE & 9.4 & 11.3 & 11.1 & 10.3 & 10.5 & 10.2 & 12.8 & 12.9 & 12.2 & 10.1 & 8.3 & 6.0 \\
\hline BUSINESS SERVICES & 4.6 & 5.7 & 5.7 & 5.0 & 4.9 & 5.0 & 5.9 & 6.3 & 5.9 & 5.2 & 4.5 & 3.6 \\
\hline
\end{tabular}

Note: See notes to Fig. 4

Table 12 Descriptive statistics of main variables by industry

\begin{tabular}{|c|c|c|c|c|}
\hline \multirow[t]{2}{*}{ Variable } & \multicolumn{2}{|c|}{ Non-zombies } & \multicolumn{2}{|c|}{ Zombies } \\
\hline & Mean & S.D. & Mean & S.D. \\
\hline \multicolumn{5}{|l|}{ MANUFACTURING } \\
\hline TFP (deviation) & 0.03 & 0.39 & -0.30 & 0.63 \\
\hline Labour productivity (deviation) & 0.31 & 2.28 & -2.82 & 5.28 \\
\hline EBITDA & 240.96 & 3339.19 & -77.57 & 673.49 \\
\hline Number of employees & 18.13 & 27.11 & 10.95 & 18.70 \\
\hline Production & 1189.85 & 2572.64 & 344.34 & 1162.84 \\
\hline GVA & 394.18 & 790.97 & 87.07 & 285.26 \\
\hline Assets & 1560.51 & 3856.44 & 682.09 & 2170.24 \\
\hline Debt & 971.19 & 2419.71 & 830.20 & 2064.15 \\
\hline \multicolumn{5}{|l|}{ Food products and beverages } \\
\hline TFP (deviation) & 0.03 & 0.37 & -0.22 & 0.51 \\
\hline Labour productivity (deviation) & 0.32 & 2.67 & -2.70 & 5.26 \\
\hline EBITDA & 256.53 & 1939.46 & -56.01 & 230.68 \\
\hline Number of employees & 17.40 & 26.49 & 9.93 & 15.74 \\
\hline Production & 1361.78 & 2976.70 & 345.80 & 1098.94 \\
\hline GVA & 385.69 & 819.46 & 72.01 & 222.03 \\
\hline Assets & 1982.55 & 4711.70 & 740.34 & 2502.00 \\
\hline Debt & 1220.22 & 2940.83 & 865.78 & 2278.62 \\
\hline \multicolumn{5}{|l|}{ Textiles and wearing apparel } \\
\hline TFP (deviation) & 0.04 & 0.45 & -0.35 & 0.79 \\
\hline Labour productivity (deviation) & 0.24 & 1.92 & -2.10 & 4.67 \\
\hline EBITDA & 83.95 & 478.16 & -72.34 & 247.47 \\
\hline Number of employees & 21.85 & 29.07 & 18.42 & 25.82 \\
\hline Production & 967.36 & 2211.01 & 340.38 & 1008.11 \\
\hline GVA & 330.18 & 649.55 & 130.17 & 314.51 \\
\hline Assets & 1017.52 & 2842.05 & 544.95 & 1743.32 \\
\hline Debt & 646.32 & 1759.92 & 744.06 & 1784.86 \\
\hline \multicolumn{5}{|l|}{ Leather and leather products } \\
\hline TFP (deviation) & 0.02 & 0.35 & -0.40 & 0.68 \\
\hline Labour productivity (deviation) & 0.14 & 1.63 & -2.34 & 4.63 \\
\hline EBITDA & 102.19 & 351.87 & -84.98 & 263.16 \\
\hline
\end{tabular}


Table 12 (continued)

\begin{tabular}{|c|c|c|c|c|}
\hline \multirow[t]{2}{*}{ Variable } & \multicolumn{2}{|c|}{ Non-zombies } & \multicolumn{2}{|l|}{ Zombies } \\
\hline & Mean & S.D. & Mean & S.D. \\
\hline Number of employees & 24.77 & 29.68 & 18.78 & 24.05 \\
\hline Production & 1219.13 & 2344.57 & 452.30 & 1082.61 \\
\hline GVA & 384.58 & 636.02 & 125.31 & 259.49 \\
\hline Assets & 969.10 & 2286.91 & 578.38 & 1340.48 \\
\hline Debt & 621.17 & 1398.89 & 899.44 & 1782.91 \\
\hline \multicolumn{5}{|l|}{ Wood and wood products; furniture } \\
\hline TFP (deviation) & 0.04 & 0.38 & -0.29 & 0.60 \\
\hline Labour productivity (deviation) & 0.44 & 2.50 & -3.11 & 5.54 \\
\hline EBITDA & 103.60 & 788.72 & -63.73 & 552.41 \\
\hline Number of employees & 13.57 & 20.05 & 7.47 & 12.36 \\
\hline Production & 812.29 & 1838.06 & 213.18 & 760.97 \\
\hline GVA & 255.93 & 548.58 & 42.91 & 145.14 \\
\hline Assets & 1133.41 & 2816.80 & 553.31 & 1766.44 \\
\hline Debt & 744.16 & 1853.33 & 675.34 & 1771.03 \\
\hline \multicolumn{5}{|c|}{ Pulp, paper, paper products and publishing } \\
\hline TFP (deviation) & 0.03 & 0.34 & -0.26 & 0.60 \\
\hline Labour productivity (deviation) & 0.29 & 1.98 & -2.80 & 5.24 \\
\hline EBITDA & 425.98 & 5006.78 & -53.48 & 196.66 \\
\hline Number of employees & 14.43 & 23.46 & 7.87 & 14.39 \\
\hline Production & 1087.17 & 2406.98 & 340.37 & 1215.11 \\
\hline GVA & 389.11 & 784.79 & 87.69 & 331.96 \\
\hline Assets & 1402.53 & 3557.31 & 518.66 & 1892.01 \\
\hline Debt & 888.60 & 2218.16 & 655.11 & 1700.40 \\
\hline \multicolumn{5}{|l|}{ Chemical and chemical products } \\
\hline TFP (deviation) & 0.03 & 0.41 & -0.34 & 0.54 \\
\hline Labour productivity (deviation) & 0.36 & 2.98 & -3.83 & 6.07 \\
\hline EBITDA & 1625.63 & 16493.63 & -517.61 & 4017.43 \\
\hline Number of employees & 28.31 & 38.18 & 13.00 & 22.69 \\
\hline Production & 3308.84 & 4481.91 & 1105.46 & 2709.10 \\
\hline GVA & 1020.11 & 1426.40 & 157.82 & 503.82 \\
\hline Assets & 4903.22 & 7331.96 & 2293.51 & 4904.96 \\
\hline Debt & 2867.71 & 4534.00 & 2262.65 & 3867.24 \\
\hline \multicolumn{5}{|c|}{ Rubber and plastic products; other non-metallic } \\
\hline TFP (deviation) & 0.03 & 0.41 & -0.24 & 0.56 \\
\hline Labour productivity (deviation) & 0.43 & 2.64 & -3.19 & 5.60 \\
\hline EBITDA & 416.50 & 5159.08 & -74.09 & 296.52 \\
\hline Number of employees & 19.95 & 29.63 & 9.10 & 17.06 \\
\hline Production & 1526.16 & 2898.55 & 350.78 & 1169.26 \\
\hline GVA & 507.88 & 928.82 & 79.73 & 290.80 \\
\hline Assets & 2304.42 & 4624.04 & 857.57 & 2391.88 \\
\hline Debt & 1408.48 & 2919.55 & 1009.10 & 2319.61 \\
\hline \multicolumn{5}{|c|}{ Basic metals and fabricated metal products } \\
\hline TFP (deviation) & 0.03 & 0.36 & -0.33 & 0.58 \\
\hline Labour productivity (deviation) & 0.28 & 2.04 & -3.08 & 5.33 \\
\hline
\end{tabular}


Table 12 (continued)

\begin{tabular}{|c|c|c|c|c|}
\hline \multirow[t]{2}{*}{ Variable } & \multicolumn{2}{|c|}{ Non-zombies } & \multicolumn{2}{|l|}{ Zombies } \\
\hline & Mean & S.D. & Mean & S.D. \\
\hline EBITDA & 146.96 & 946.07 & -61.42 & 408.06 \\
\hline Number of employees & 14.78 & 22.99 & 7.38 & 11.98 \\
\hline Production & 1003.76 & 2181.80 & 246.92 & 782.55 \\
\hline GVA & 365.10 & 726.42 & 61.08 & 199.68 \\
\hline Assets & 1287.79 & 3225.30 & 505.00 & 1525.85 \\
\hline Debt & 818.51 & 2054.76 & 630.47 & 1570.49 \\
\hline \multicolumn{5}{|l|}{ Electronic and electrical equipment } \\
\hline TFP (deviation) & 0.03 & 0.41 & -0.34 & 0.66 \\
\hline Labour productivity (deviation) & 0.33 & 2.52 & -3.45 & 5.69 \\
\hline EBITDA & 816.66 & 4517.30 & -246.22 & 1636.42 \\
\hline Number of employees & 28.47 & 40.07 & 14.84 & 26.80 \\
\hline Production & 2367.14 & 3905.07 & 831.71 & 2386.50 \\
\hline GVA & 810.71 & 1272.31 & 162.96 & 513.00 \\
\hline Assets & 3308.24 & 6088.08 & 1276.14 & 3243.04 \\
\hline Debt & 1975.25 & 3826.57 & 1485.70 & 2963.78 \\
\hline \multicolumn{5}{|l|}{ Machinery and equipment } \\
\hline TFP (deviation) & 0.02 & 0.37 & -0.32 & 0.78 \\
\hline Labour productivity (deviation) & 0.23 & 2.07 & -3.16 & 5.50 \\
\hline EBITDA & 335.44 & 2789.73 & -95.02 & 398.54 \\
\hline Number of employees & 19.93 & 28.06 & 11.16 & 17.37 \\
\hline Production & 1557.24 & 2758.79 & 487.20 & 1332.56 \\
\hline GVA & 563.55 & 924.15 & 120.02 & 291.53 \\
\hline Assets & 2083.09 & 4190.30 & 1119.56 & 2770.81 \\
\hline Debt & 1189.85 & 2455.25 & 1302.06 & 2725.39 \\
\hline \multicolumn{5}{|c|}{ Motor vehicles, trailers and other transport equipment } \\
\hline TFP (deviation) & 0.03 & 0.47 & -0.30 & 0.58 \\
\hline Labour productivity (deviation) & 0.29 & 2.62 & -2.96 & 5.48 \\
\hline EBITDA & 914.88 & 6329.63 & -233.40 & 1421.25 \\
\hline Number of employees & 36.40 & 45.96 & 20.16 & 34.93 \\
\hline Production & 2953.31 & 4446.71 & 1293.80 & 3143.70 \\
\hline GVA & 971.16 & 1426.11 & 306.43 & 867.75 \\
\hline Assets & 4063.06 & 6943.42 & 1992.79 & 4688.89 \\
\hline Debt & 2603.24 & 4538.67 & 2145.44 & 3952.74 \\
\hline \multicolumn{5}{|c|}{ Other manufacturing n.e.c. and recycling } \\
\hline TFP (deviation) & 0.03 & 0.44 & -0.41 & 0.72 \\
\hline Labour productivity (deviation) & 0.25 & 2.25 & -2.96 & 5.31 \\
\hline EBITDA & 116.59 & 854.50 & -50.72 & 281.90 \\
\hline Number of employees & 11.45 & 19.89 & 6.97 & 12.23 \\
\hline Production & 691.41 & 1788.84 & 281.14 & 1159.62 \\
\hline GVA & 280.67 & 621.99 & 73.34 & 286.96 \\
\hline Assets & 920.14 & 2681.58 & 526.97 & 1629.27 \\
\hline Debt & 561.79 & 1705.45 & 639.84 & 1607.68 \\
\hline \multicolumn{5}{|l|}{ CONSTRUCTION } \\
\hline TFP (deviation) & 0.05 & 0.51 & -0.45 & 0.79 \\
\hline
\end{tabular}


Table 12 (continued)

\begin{tabular}{|c|c|c|c|c|}
\hline \multirow[t]{2}{*}{ Variable } & \multicolumn{2}{|c|}{ Non-zombies } & \multicolumn{2}{|l|}{ Zombies } \\
\hline & Mean & S.D. & Mean & S.D. \\
\hline Labour productivity (deviation) & 0.34 & 2.78 & -3.07 & 5.79 \\
\hline EBITDA & 78.92 & 950.10 & -66.74 & 909.95 \\
\hline Number of employees & 10.12 & 16.47 & 6.85 & 11.66 \\
\hline Production & 584.19 & 1543.97 & 400.93 & 1339.41 \\
\hline GVA & 206.12 & 493.16 & 72.23 & 278.48 \\
\hline Assets & 991.64 & 2859.39 & 1571.78 & 3975.59 \\
\hline Debt & 671.09 & 1951.65 & 1435.44 & 3101.64 \\
\hline \multicolumn{5}{|l|}{ TRADE } \\
\hline TFP (deviation) & 0.05 & 0.48 & -0.43 & 0.67 \\
\hline Labour productivity (deviation) & 0.41 & 2.82 & -3.43 & 5.75 \\
\hline EBITDA & 107.84 & 1355.42 & -45.27 & 280.41 \\
\hline Number of employees & 8.61 & 14.87 & 5.56 & 10.42 \\
\hline Production & 442.17 & 1257.28 & 154.84 & 675.05 \\
\hline GVA & 221.39 & 512.29 & 46.91 & 205.99 \\
\hline Assets & 1049.97 & 2631.95 & 554.91 & 1758.19 \\
\hline Debt & 688.87 & 1749.65 & 669.27 & 1608.06 \\
\hline \multicolumn{5}{|l|}{ ACCOMMODATION } \\
\hline TFP (deviation) & 0.04 & 0.45 & -0.21 & 0.57 \\
\hline Labour productivity (deviation) & 0.51 & 3.51 & -2.85 & 5.75 \\
\hline EBITDA & 39.94 & 421.87 & -28.36 & 121.61 \\
\hline Number of employees & 8.79 & 14.81 & 5.32 & 9.01 \\
\hline Production & 322.45 & 961.56 & 125.48 & 523.27 \\
\hline GVA & 133.03 & 387.78 & 30.40 & 175.12 \\
\hline Assets & 563.89 & 2331.81 & 236.39 & 1514.20 \\
\hline Debt & 375.73 & 1491.01 & 337.35 & 1271.60 \\
\hline \multicolumn{5}{|l|}{ REAL ESTATE } \\
\hline TFP (deviation) & 0.05 & 0.74 & -0.37 & 0.80 \\
\hline Labour productivity (deviation) & 0.47 & 4.91 & -3.15 & 6.45 \\
\hline EBITDA & 122.42 & 828.64 & -65.83 & 465.96 \\
\hline Number of employees & 5.31 & 9.42 & 4.78 & 9.77 \\
\hline Production & 491.68 & 1373.66 & 357.57 & 1313.82 \\
\hline GVA & 194.83 & 524.59 & 57.71 & 253.27 \\
\hline Assets & 2473.48 & 5045.52 & 2594.47 & 5404.62 \\
\hline Debt & 1493.63 & 3258.21 & 2384.33 & 4251.50 \\
\hline \multicolumn{5}{|l|}{ BUSINESS SERVICES } \\
\hline TFP (deviation) & 0.03 & 0.52 & -0.45 & 0.82 \\
\hline Labour productivity (deviation) & 0.21 & 2.65 & -2.81 & 5.41 \\
\hline EBITDA & 111.66 & 1388.98 & -76.34 & 627.53 \\
\hline Number of employees & 10.46 & 21.45 & 8.75 & 19.96 \\
\hline Production & 655.67 & 1794.30 & 450.92 & 1585.80 \\
\hline GVA & 286.24 & 683.41 & 134.53 & 484.54 \\
\hline Assets & 976.48 & 3232.68 & 867.66 & 3033.40 \\
\hline Debt & 607.21 & 2023.98 & 951.27 & 2556.81 \\
\hline
\end{tabular}

Note: See notes to Table 1 
Table 13 Descriptive statistics of the main variables in the pre-crisis, crisis and recovery periods

\begin{tabular}{|c|c|c|c|c|c|c|}
\hline \multirow[t]{2}{*}{ Variable } & \multicolumn{2}{|l|}{ Pre-crisis } & \multicolumn{2}{|l|}{ Crisis } & \multicolumn{2}{|l|}{ Recovery } \\
\hline & Mean & S.D. & Mean & S.D. & Mean & S.D. \\
\hline \multicolumn{7}{|c|}{ Non-zombies } \\
\hline TFP (deviation) & 0.04 & 0.43 & 0.05 & 0.49 & 0.04 & 0.51 \\
\hline Labour productivity (deviation) & 0.28 & 2.39 & 0.38 & 2.98 & 0.41 & 3.07 \\
\hline EBITDA & 131.32 & 1936.42 & 115.79 & 1726.56 & 124.49 & 1875.39 \\
\hline Number of employees & 11.52 & 19.74 & 10.85 & 19.22 & 10.62 & 19.38 \\
\hline Production & 671.11 & 1744.00 & 619.67 & 1709.85 & 621.28 & 1733.11 \\
\hline GVA & 262.79 & 598.85 & 244.95 & 588.02 & 250.54 & 604.96 \\
\hline Assets & 1045.02 & 2916.70 & 1136.20 & 3168.21 & 1123.25 & 3192.64 \\
\hline Debt & 707.11 & 1935.25 & 734.81 & 2057.09 & 677.00 & 1993.31 \\
\hline \multicolumn{7}{|c|}{ Zombies } \\
\hline TFP (deviation) & -0.34 & 0.62 & -0.37 & 0.70 & -0.39 & 0.75 \\
\hline Labour productivity (deviation) & -2.49 & 5.20 & -3.11 & 5.72 & -3.69 & 5.98 \\
\hline EBITDA & -34.82 & 440.51 & -63.12 & 584.87 & -59.19 & 541.85 \\
\hline Number of employees & 8.22 & 14.67 & 6.98 & 13.76 & 5.67 & 11.49 \\
\hline Production & 380.00 & 1277.34 & 244.08 & 997.78 & 165.10 & 750.61 \\
\hline GVA & 94.39 & 329.71 & 60.35 & 263.06 & 39.36 & 201.08 \\
\hline Assets & 993.18 & 2917.04 & 787.88 & 2678.27 & 565.68 & 2317.31 \\
\hline Debt & 1008.27 & 2401.59 & 849.09 & 2244.58 & 681.56 & 1987.31 \\
\hline
\end{tabular}

Note: See notes to Table 1

Table 14 Descriptive statistics of covariates included in the multinomial logistic regression

\begin{tabular}{llll}
\hline Variables & Continuing zombies & Recovery & Exit \\
\hline$\Delta$ Log Employment & $-0.082(0.404)$ & $-0.080(0.408)$ & $-0.273(0.580)$ \\
$\Delta$ Log Assets & $-0.099(0.415)$ & $-0.079(0.442)$ & $-0.467(0.823)$ \\
$\Delta$ Log TFP & $-0.129(0.557)$ & $-0.014(0.563)$ & $-0.255(0.919)$ \\
$\Delta$ Log Labour productivity & $-1.444(7.538)$ & $-0.320(7.083)$ & $-3.404(9.033)$ \\
Log Leverage & $0.556(0.649)$ & $0.392(0.550)$ & $0.845(0.788)$ \\
Log Return-on-assets & $-8.727(1.464)$ & $-8.418(1.827)$ & $-8.995(0.968)$ \\
Log Zombie duration & $0.650(0.658)$ & $0.648(0.569)$ & $0.826(0.585)$ \\
Log Employment & $1.405(0.877)$ & $1.467(0.908)$ & $1.146(0.985)$ \\
Log Assets & $11.874(1.665)$ & $12.077(1.680)$ & $11.483(1.833)$ \\
Log Age & $2.523(0.510)$ & $2.497(0.501)$ & $2.385(0.325)$ \\
\hline
\end{tabular}

Notes: Mean values and standard deviations (in parentheses). The variables are defined in the text. The variables were winsorised at the $1 \mathrm{st}$ and 99th percentiles. Pooled yearly values, 2005-2016 


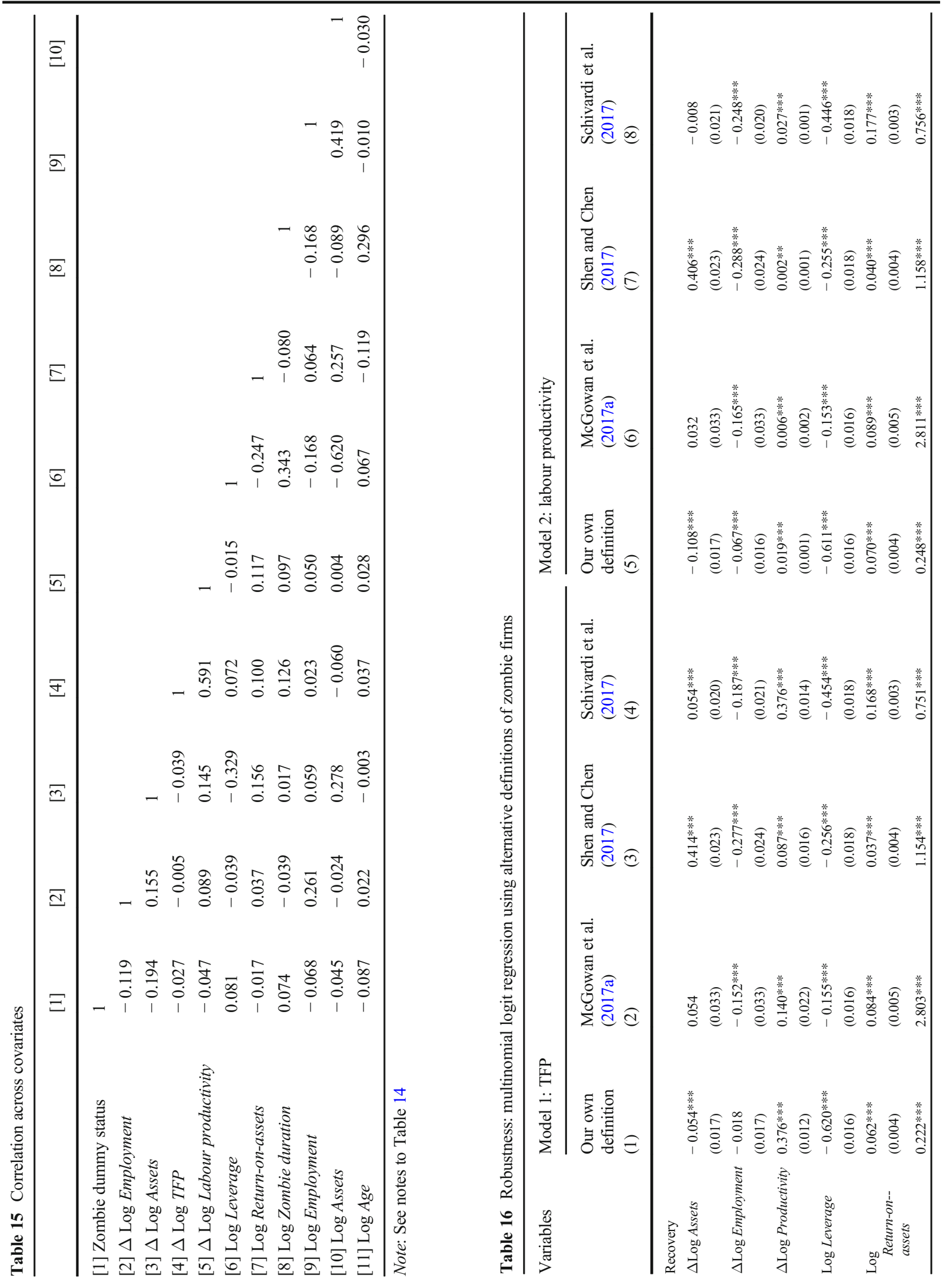




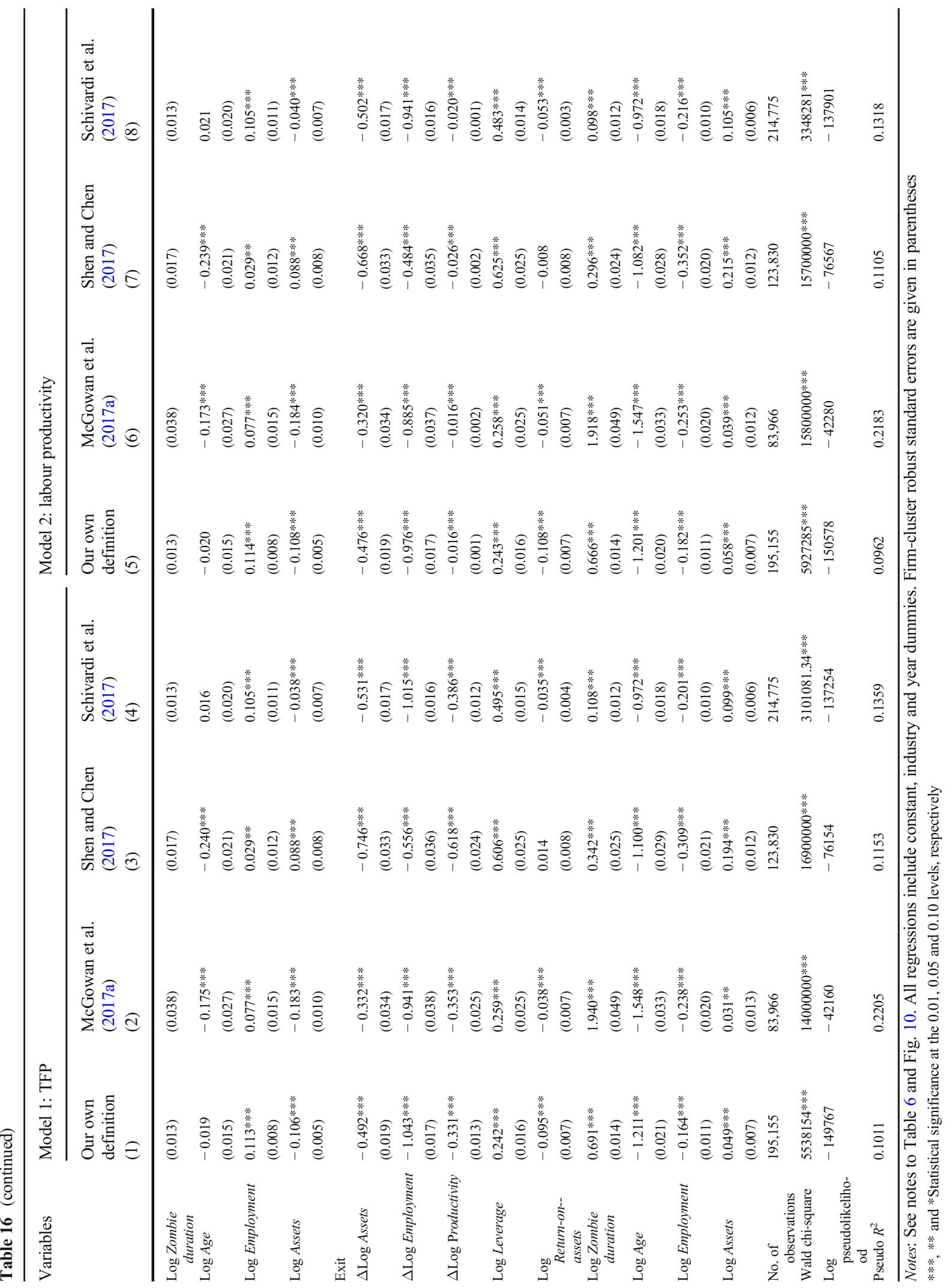


Table 17 Ordered logit regression

\begin{tabular}{|c|c|c|}
\hline Variables & $\begin{array}{l}\text { Model 1: TFP } \\
\text { (1) }\end{array}$ & $\begin{array}{l}\text { Model 2: labour productivity } \\
\text { (2) }\end{array}$ \\
\hline$\Delta \log$ Assets & $0.618 * * *(0.012)$ & $0.545 * * *(0.012)$ \\
\hline$\Delta$ Log Employment & $0.278 * * *(0.013)$ & $0.237 * * *(0.013)$ \\
\hline$\Delta \log$ Productivity & $0.442 * * *(0.010)$ & $0.022 * * *(0.001)$ \\
\hline Log Leverage & $-0.589 * * *(0.011)$ & $-0.592 * * *(0.011)$ \\
\hline Log Return-on-assets & $0.073 * * *(0.003)$ & $0.085 * * *(0.003)$ \\
\hline Log Zombie duration & $-0.097 * * *(0.009)$ & $-0.061 * * *(0.009)$ \\
\hline Log Age & $0.342 * * *(0.009)$ & $0.340 * * *(0.009)$ \\
\hline Log Employment & $0.158 * * *(0.007)$ & $0.171 * * *(0.007)$ \\
\hline Log Assets & $-0.098 * * *(0.004)$ & $-0.107 * * *(0.004)$ \\
\hline \multicolumn{3}{|l|}{ Industry dummy: } \\
\hline Construction & $0.087 * * *(0.018)$ & $0.064 * * *(0.018)$ \\
\hline Trade & $0.087 * * *(0.014)$ & $0.091 * * *(0.014)$ \\
\hline Accommodation & $0.286 * * *(0.016)$ & $0.294 * * *(0.016)$ \\
\hline Real estate & $0.422 * * *(0.029)$ & $0.425 * * *(0.029)$ \\
\hline Business services & $0.358 * * *(0.020)$ & $0.343 * * *(0.020)$ \\
\hline \multicolumn{3}{|l|}{ Year dummy: } \\
\hline 2006 & $-0.101 * * *(0.024)$ & $-0.110 * * *(0.023)$ \\
\hline 2007 & $-0.069 * * *(0.025)$ & $-0.089 * * *(0.025)$ \\
\hline 2008 & $0.073 * * *(0.026)$ & $0.040(0.026)$ \\
\hline 2009 & $0.155 * * *(0.027)$ & $0.133 * * *(0.027)$ \\
\hline 2010 & $-0.243 * * *(0.024)$ & $-0.263 * * *(0.024)$ \\
\hline 2011 & $-0.365 * * *(0.024)$ & $-0.400 * * *(0.024)$ \\
\hline 2012 & $-0.164 * * *(0.025)$ & $-0.195 * * *(0.025)$ \\
\hline 2013 & $-0.083 * * *(0.025)$ & $-0.092 * * *(0.025)$ \\
\hline 2014 & $0.108 * * *(0.026)$ & $0.103 * * *(0.026)$ \\
\hline 2015 & $0.139 * * *(0.027)$ & $0.135 * * *(0.027)$ \\
\hline 2016 & $-0.824 * * *(0.023)$ & $-0.816 * * *(0.023)$ \\
\hline \multicolumn{3}{|l|}{ Threshold: } \\
\hline Cutpoint 1 & $-3.368 * * *(0.068)$ & $-3.507 * * *(0.068)$ \\
\hline Cutpoint 2 & $0.247 * * *(0.067)$ & $0.080(0.067)$ \\
\hline No. of observations & 195,155 & 195,155 \\
\hline Wald chi-square & $20586^{* * *}$ & $19983 * * *$ \\
\hline Log pseudolikelihood & -156210 & -157110 \\
\hline Pseudo $R^{2}$ & 0.0624 & 0.0570 \\
\hline
\end{tabular}

Notes: Ordered logit model, assuming three ordered categories: $1=$ exit, 2 = remaining as a zombie, $3=$ recovery. The variables were winsorised at the 1 st and 99 th percentiles. Firm-cluster robust standard errors are given in parentheses $* * *, * *$ and $*$ Statistical significance at the $0.01,0.05$ and 0.10 levels, respectively 
Open Access This article is licensed under a Creative Commons Attribution 4.0 International License, which permits use, sharing, adaptation, distribution and reproduction in any medium or format, as long as you give appropriate credit to the original author(s) and the source, provide a link to the Creative Commons licence, and indicate if changes were made. The images or other third party material in this article are included in the article's Creative Commons licence, unless indicated otherwise in a credit line to the material. If material is not included in the article's Creative Commons licence and your intended use is not permitted by statutory regulation or exceeds the permitted use, you will need to obtain permission directly from the copyright holder. To view a copy of this licence, visit http://creativecommons.org/licenses/by/4.0/.

\section{References}

Ahmad, N. (2006). A proposed framework for business demography statistics. OECD Statistics Working Papers: 2006/3. OECD Publishing, Paris.

Andrews, D., F. Petroulakis (2017). Breaking the shackles: zombie firms, weak banks and depressed restructuring in Europe. OECD Economics Department Working Papers No. 1433. OECD Publishing, Paris.

Banerjee, R., Hofmann, B. (2018). The rise of zombie firms: causes and consequences. BIS Quarterly Review, September, 12pp. https:/www.bis.org/publ/qtrpdf/r_qt1809 g.htm. Accessed 12/11/2018.

Bartelsman, E. J., \& Doms, M. (2000). Understanding productivity: lessons from longitudinal micro-data. Journal of Economic Literature, 38(2), 569-594.

Borio, C., Hofmann, B. (2017). Is monetary policy less effective when interest rates are persistently low? BIS Working Papers No 628.

Caballero, R., \& Hammour, M. (1998). The macroeconomics of specificity. Journal of Political Economy, 106(4), 724-767.

Caballero, R., \& Hammour, M. (2000). Creative destruction and development: institutions, crises, and restructuring. NBER Working Paper, 7849, 1-41.

Caballero, R., Hoshi, T., \& Kashyap, A. K. (2008). Zombie lending and depressed restructuring in Japan. American Economic Review, 98(5), 1943-1977.

Carreira, C., \& Teixeira, P. (2011). The shadow of death: analysing the pre-exit productivity of Portuguese manufacturing firms. Small Business Economics, 36(3), 337-351.

Carreira, C., \& Teixeira, P. (2016). Entry and exit in severe recessions: lessons from the 2008-2013 Portuguese economic crisis. Small Business Economics, 46(4), 591-617.

Foster, L., Haltiwanger, J., \& Syverson, C. (2008). Reallocation, firm turnover, and efficiency: selection on productivity or profitability? American Economic Review, 98(1), 394-425.

Fukuda, S., \& Nakamura, J. (2011). Why Did 'Zombie' Firms Recover in Japan? World Economy, 34(7), 1124-1137.

Gouveia, A. F., Osterhold, C. (2018). Fear the walking dead: zombie firms, spillovers and exit barriers. OECD Productivity Working Papers, 2018-13. OECD Publishing, Paris.
INTRUM (2018). European Payment Industry White Paper. https://www.intrum.com/press/publications/europeanpayment-industry-white-paper. Accessed 12/11/2018.

Koski, H., \& Pajarinen, M. (2013). The role of business subsidies in job creation of start-ups, gazelles and incumbents. Small Business Economics, 41(1), 195-214.

Kwon, H. U., Narita, F., \& Narita, M. (2015). Resource reallocation and zombie lending in Japan in the 1990s. Review of Economic Dynamics, 18(4), 709-732.

Levinsohn, J., \& Petrin, A. (2003). Estimating production functions using inputs to control for unobservables. Review of Economic Studies, 70(2), 317-341.

Mata, J., \& Portugal, P. (2004). Patterns of entry, post-entry growth and survival. Small Business Economics, 22(3-4), 283-298.

McGowan, M., Andrews, D., Millot, V. (2017a). The walking dead? Zombie firms and productivity performance in OECD countries. OECD Economics Department Working Papers No. 1372. OECD Publishing, Paris.

McGowan, M., Andrews, D., Millot, V. (2017b). Insolvency regimes, zombie firms and capital reallocation. OECD Economics Department Working Papers, No. 1399. OECD Publishing, Paris.

McGowan, M., Andrews, D., Millot, V. (2017c). Insolvency regimes, technology diffusion and productivity growth: evidence from firms in OECD countries. OECD Economics Department Working Papers No 1425. OECD Publishing, Paris.

Moosa, I. (2010). The myth of too big to fail. Journal of Banking Regulation, 11(4), 319-333.

Nakamura, J. (2017). Evolution and recovery of zombie firms: Japan's experience. In J. Nakamura (Ed.), Japanese Firms During the Lost Two Decades (pp. 7-36). Springer.

Peek, J., \& Rosengren, E. (2005). Unnatural selection: perverse incentives and the misallocation of credit in Japan. American Economic Review, 95(4), 1144-1166.

Rovigatti, G., \& Mollis, V. (2018). Theory and practice of totalfactor productivity estimation: the control function approach using Stata. Stata Journal, 18(3), 618-662.

Schivardi, F., Sette, E., Tabellini, G. (2017). Credit misallocation during the European Financial Crisis. CEPR Discussion Paper No. DP11901.

Shen, G., \& Chen, B. (2017). Zombie firms and over-capacity in Chinese manufacturing. China Economic Review, 44, 327-342.

Storz, M., Koetter, M., Setzer, R., Westphal, A. (2017). Do we want these two to tango? On Zombie Firms and Stressed Banks in Europe. ECB Working Paper No. 2104. European Central Bank, Frankfurt.

Syverson, C. (2011). What determines productivity? Journal of Economic Literature, 49(2), 326-365.

van Biesebroeck, J. (2008). The sensitivity of productivity estimates: revisiting three important debates. Journal of Business and Economic Statistics, 26(3), 311-328.

Tan, Y., Huang, Y., \& Woo, W. T. (2016). Zombie firms and the crowding-out of private investment in China. Asian Economic Papers, 15(3), 32-55.

Publisher's note Springer Nature remains neutral with regard to jurisdictional claims in published maps and institutional affiliations. 